\title{
مسؤولية المثزيثة العامة عن أعمال القضاة الجزائية
}

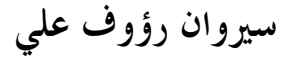 \\ الخامي المستشار \\ ماجستير في القانون الخاص
}

\author{
بكتيار صديق رحيم \\ مدرس القانون الحخاص بجامعة السليمانية \\ محاضر في جامعة جيهان/السليمانية
}

الملخصص

أن الضرر يعد ركناً من أركان المسؤولية المدنية، بحيث تنثفي المسؤولية بإنتفائه، وأن محو الضرر ومساعدة المضرور أصبح

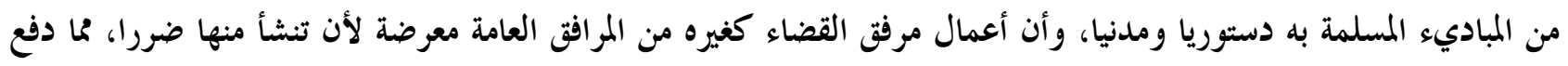

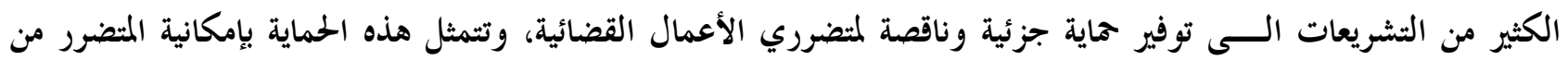
مخاصمة الحزينة العامة ومطالبته بالتعويض جراء الضرر الذي اصابه.

\section{يوخته:}

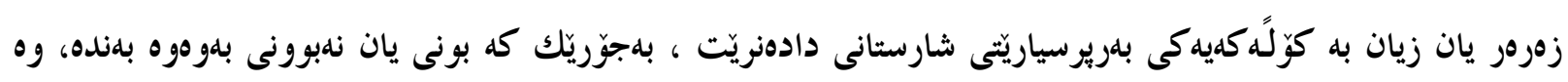

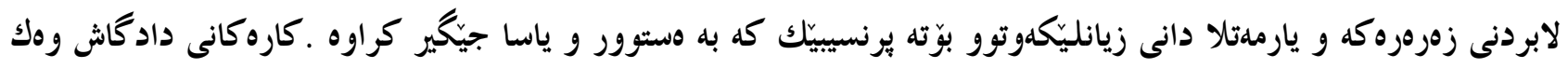

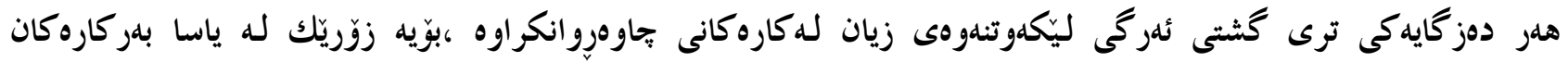

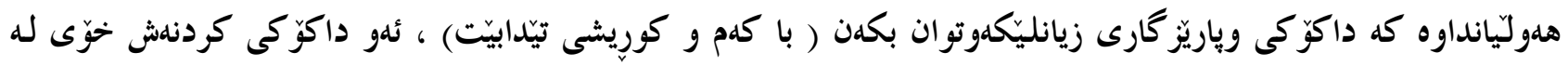

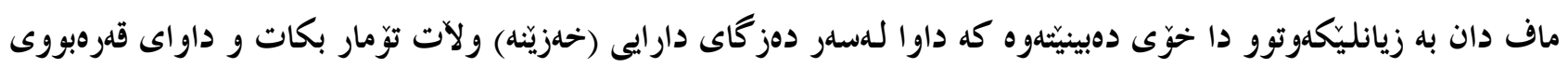
ئهو زيانانه بكات كه ليّى كهوتووه.

\section{Abstract:}

That the damage is a cornerstone of civil liability, thereby eliminating the responsibility Bantvaih, and erase the damage and help the injured become a Muslim by the principles of the constitution and a civilian, and that works facility judiciary, like other public utilities vulnerable because arise, including damage, prompting a lot of legislation to provide partial protection and incomplete for the victims of judicial work, and this protection is the possibility of strife affected the public treasury and its demand due to the damage that injury compensation. 


\section{المقدمة}

تعد السلطة القضائية هي الحامية لحقوق الافراد وحرياتهم، وهي التي تعطى للقانون فاعليته وإلزامه، إذ بغير هذه السلطة لايعدو القانون سوى قواعد نظرية لايوجد من يحقق لها صفته الإلزامية الآمرة، ولكي تقوم هذه السلطة بأداء المهمة الملقاة على عاتقها على أحسن وجه، فقد وفر المشرع لأعضائها ضمانات من شأنها أن تساعد تلك السلطة على تحقيق أهدافها، ووضع

الإجر اءات التي تمنع الوقوع في الخطأ كما نظم طرق الطعن في الأحكام، حتى يكون الحكم الصادر عنواناً للحقيقة ومظهراً لها. وعلى رغم من هذه الضمانات وكثرتها فإن إحتمال وقوع القاضي في الخظور لم يكن أمرا مستبعداً، ويعد من الامور المسلم بها، نظراً لحساسية عمله ودقته، لذا فإن نهوض المسؤولية المدنية عن أعمال تلك السلطة أمر وارد ومسلم به أيضاً ويعد تساؤلاً في محله. وقد أخذت المسؤولية عن الأعمال القضائية في الوقت الحاضر شكلين من الأنظمة القانونية، فالشكل الأول هو النظام

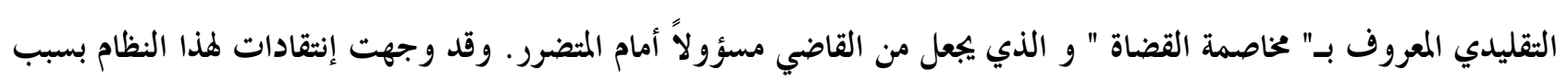
عدم مواكبته للتطورات التي طرأت على أحكام المسؤولية، مما دفع الفقه إلى التوجه نحو نظام جديد يستجيب لتلك التطورات، ويستكمل أوجه النقص المشوب بالنظام التقليدي، وهذا النظام الجديد هو نظام "مخاصمة الخزينة العامة"، والذي يعد الشكل

$$
\text { الثاني من أنظمة المسؤولية عن العمل القضائي. }
$$

لذا نسعى في هذا البحث أن نسلط الضوء على المسؤولية المدنية للخزينة العامة عن الأعمال القضائية في المسائل الجزائية دون المسائل المدنية. وذلك في مبحثين نخصص الأول منهما لبيان مسؤولية الحزينة في الحالات التي يحكم فيها بالبراءة بعد إعمال طريق إعادة الخاكمة، فيما نخصص الثاني لحالات التوقيف في دراسة مقارنة بين مجموعة قوانين هي القانون الفرنسي والمصري واليبي والجزائري واللبناني مع القانون النافذ في العراق وإقليم كوردستان . 


\section{المبحث الأول}

\section{مسؤولية الحزينة عن الأحكام الجنائية التي يحكم فيها بالبراءة بعد إعادة الغحاكمة}

نتناول في هذا المبحث مسؤولية الحزينة العامة عند الحكم بالبراءة بعد إعادة الخاكمة في مطلبين، نخصص الأول لموقف القوانين المقارنة، فيما ندرس في الثاني موقف المشرع العراقي والكوردستاني منها.

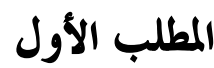

\section{مسؤولية المخزينة عن الأحكام الجنائية التي يحكم فيها بالبراءة في القواين المقارئة}

من المتفق عليه أن الاحكام القضائية بصفة عامة وإن كانت تتمتع بحجية الشيء المقضي والذي يعني أنما قضت به هي عنوان الحقيقة، إلا إنها لاتقرر إلا حقيقة نسبية يصل إليها القاضي بناءً على الأدلة المطروحة أمامه. لذا فإن وقوع القاضي في الخطأ أو

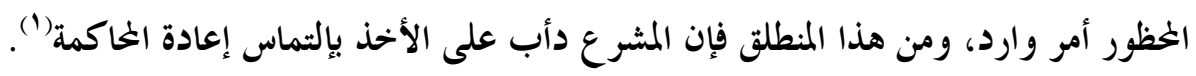

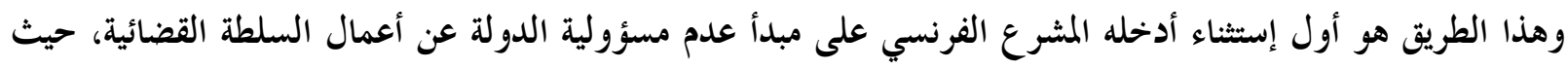

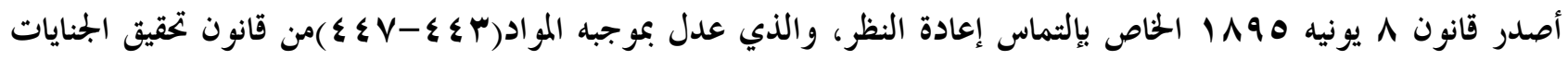

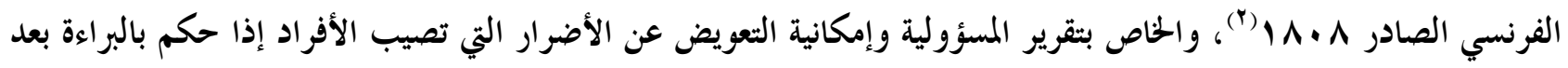
إلتماس إعادة النظر، أي يتزتب على ذلك أنه يجوز للافراد طلب التعويض عن الأضرار التي أصابتهم جر اء الحكم السابق بالإدانة

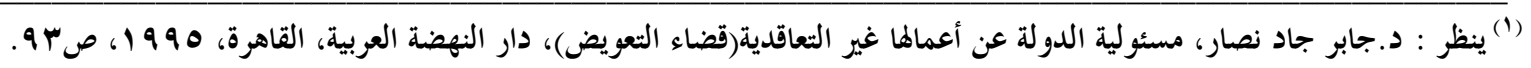

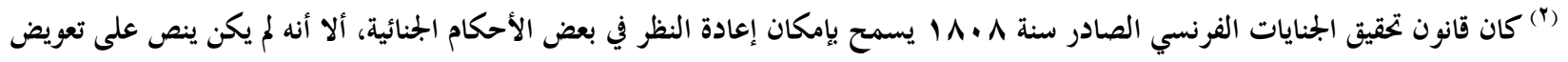

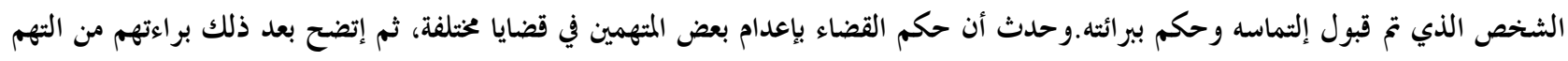

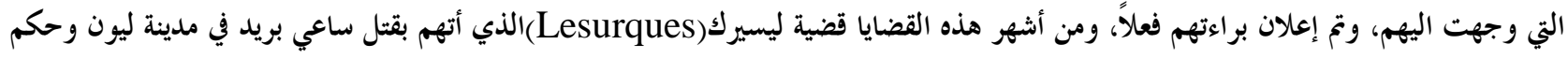

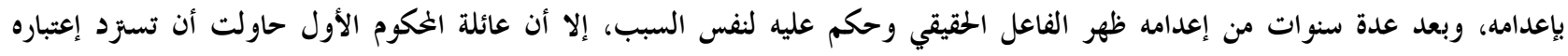

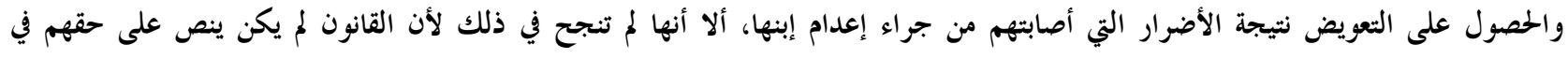

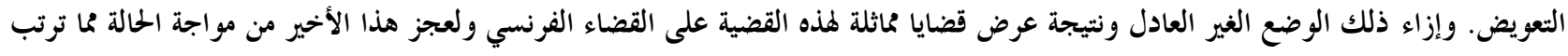

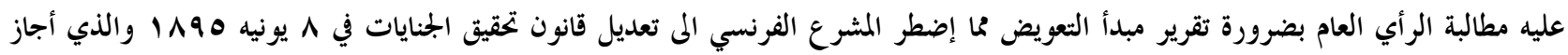

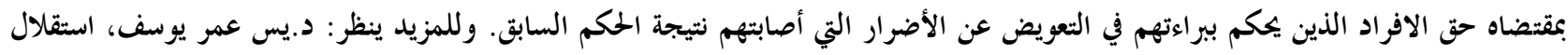

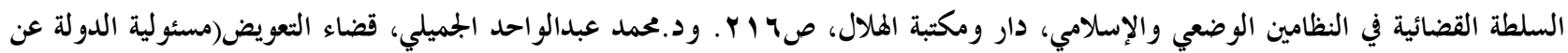


وفق الشروط الخددة للطعن(1). ويعد هذا التعديل كما قال تارجيه(Target)أحد أعضاء اللجنة المشكلة لتعديل القانون( ان منح التعويض لمن يجكم ببراءته بمثابة شهادة من الجُتمع بأن المتهم طاهر الذيل)("). فإذا حكم ببراءة الخكوم عليه نتيجة توافر حالة من الحالات السابقة، فإن القانون يقرر له الحقى في الحصول على تعويض من الدولة عن الأضرار التي لحقته نتيجة الحكم بإدانته، بشرط أن لايكون الحكم صدر بحقه بسبب خطأ الخكوم عليه نفسه(").حيث لم يشتزط المشرع للحصول على التعويض أن يثبت طالب التعويض أن الغكمة حين إصدارها لحكمها السابق بالإدانة قد وقعت في خطأ، بل أن مجرد إبطال الحكم السابق بالإدانة وإصدار حكم جديد بالبراءة يرتب له الحقى في التعويض مباشرة تجاه الدولة(؛)؛ ويقدر هذا التعويض حسب ظروف كل حالة على حدة وللمحكمة سلطة تقديرية في ذلك، وأن أساس هذا التعويض ليس الحطأ بل المخاطر، وللدولة أن ترجع بمقدار التعويض على من كان سبباً في خطأ القضاء كالمبلغ وشهود الزور والمدعى المدني. كما وأوجب المشرع ضرورة نشر الحكم الصادر بالبراءة بناء على إلتماس إعادة النظر على نفقة الدولة في المدينة التي صدر فيها الحكم الأول وحكم البراءة وفي المكان الذي أرتكب فيه الجريمة وفي موطن طالب إعادة النظر، وفي آخر موطن للمحكوم عليه

(1) للمزيد حول هذه الشروط ينظر : د.سعيد السيد علي، نطاق وأحكام مسؤولية الدولة، دراسة مقارنة،دار الكتاب الحديث، ب ا •r، ص

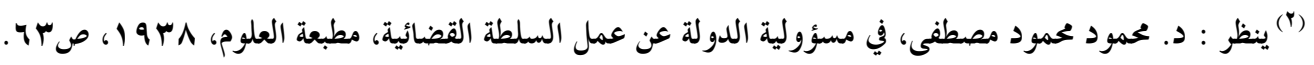
(") قد يحدث أن تحكم الخكمة على شخص نتيجة إعنز اف هذا الشخص بإقز افه للفعل المسند اليه، ولكن في الحقيقة أنه ليس بالفاعل بل أن غرضه من ذلك هو لإخفاء الفاعل الحقيقي وتهربه من العقوبة، ففي هذه الحالة يعد اعتزافه سببا لوقوع الخكمة في الحطأ ومن ثم صدور حكم الادانة والعقوبة بحقه، لذا فليس من العدل أن يمنح هذا الشخص حق طلب التعويض لسكوته عن الدفاع عن نفسه أولا واعز افه اعتزافا كاذبا لتضليل العدالة عن المتهم الحقيقي ثانيا تطبيقا للقو اعد العامة في القانون المدنى لانه قد إشترك بخطئه في احداث الضرر وزاد فيه(المادة ـ إب من القانون المدني العر اقي).

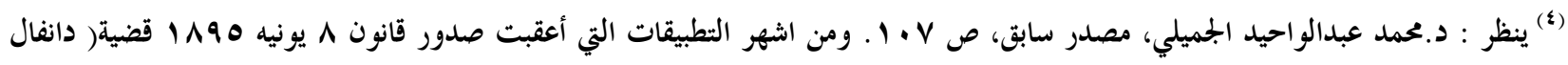

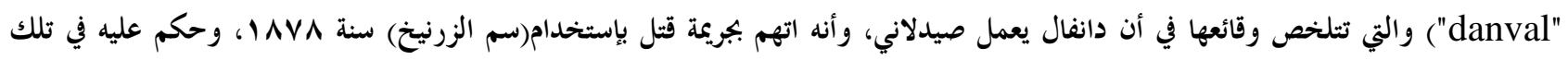
السنة بالسجن مدى الحياة، ولكن ثبت بعد ذلك علميا أن كمية السم التي وجدت في إحشاء الجنى عليه لاتكفي لقتله، فضلا عن أنه من الممكن أن تكون هذه الكمية متولدة طبيعيا في الجسم، وإستنادا لهذه الحقائق العلمية تقدم الخكوم(دانفال)بإلتماس إعادة النظر في الحكم الصادر بحقه المى محكمة

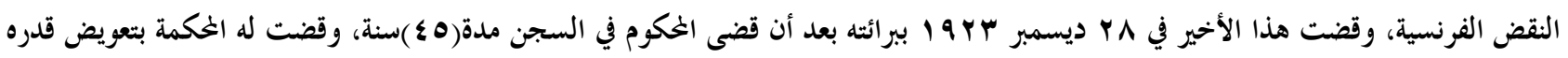
مائتي ألف فرانك فرنسي، فضلا عن راتب سنوي مدى الحياة قدره اثنى عشر ألف فرنك. وكذلك قضية السيدة(يوليو دريو) حيث كانت هذه السيدة تقيم مع زوجها وأخاها، وفي ذات اليوم وجد كل من الزوج والاخ جثة هامدة في البيت، واتجهت الشكوك اليها وأبمع الرأي العام على

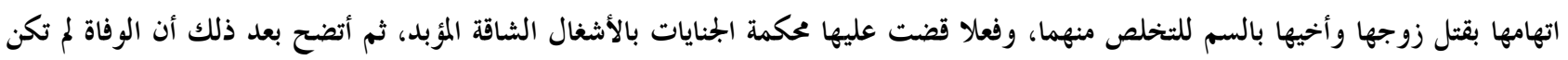
بفعل جناية بل كانت نتيجة للإختناق بالغازات الصادرة المتصاعدة من كابينة مولعة بجانب المنزل الذي كانت تقيم فيه السيدة والخنى عليهما، إذ وقعت حالات وفاة جديدة أخرى بنفس الحالة التي توفى الزوج والاخ المذكوران وثبت بما لايدع بجالا للشك وجود شقوق في الحائط الفاصل بين المنزل والكامينة تتسرب منها الغازات السامة الى سكان المنزل فتصيبهم بالدوار والغثيان وقد ينتهي بالوفاة وبناء على هذه الوقائع الجديدة أعيد النظر في الحكم وقضى ببراءتها والتعويض، أشار اليه د.جابر جاد نصار، مصدر سابق، ص 90. 
الذي ظهرت برائته إذا كان قد توفي اثناء ذلك علاوة على نشر الحكم في الجريدة الرسمية وفي خمس جرائد اخرى متى طلب أصحاب الشأن ذلك(').

هذا ويكون الحكم بالتعويض للمتهم الذي حكم ببرائته، وفي حال وفاته فإنه يكون للزوج أو الأصول أو الفروع أو لمن يثبت من الأقارب أنه لحقه ضرر مادي من الحكم الخاطيء، ويختلف تقدير التعويض بإختلاف طالبه، فإذا كان طالب التعويض هو ذات الخكوم عليه الذي قضى فيما بعد ببرائته أو زوجه أو فروعه أو أصوله في حالة وفاته، وجب أن يراعي في التعويض الضرر المادي والأدبي معاً، أما إذا كان طالب التعويض بقية الأقارب، فلا يراعي إلا الضرر المادي وحده(؟). وأن هناك إنتقادات وجهت لهذا التعديل منها إقنصار أحكامه على حالة واحدة وهي صدور الحكم بالبراءة ولم يشمل حالات التوقيف أو صدور الحكم بالإفراج، وكذلك لم يمتد أحكامه إلى الأحكام المدنية وأحكام القضاء الإداري. ونتيجة لهذه الإنتقادات فقد تدخل المثرع الفرنسي عام 9VY (19، وخرج عن القاعدة العامة والمتمثلة في عدم مسؤولية

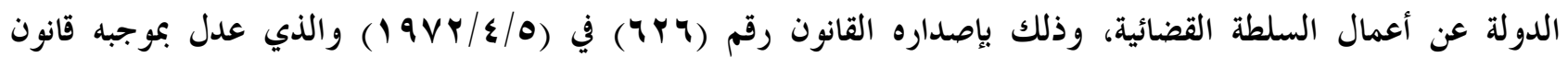
المرافعات المدنية، بإقراره قاعدة جديدة مؤداها أن تسأل الدولة عن أعمال القضاء في حالين وهما حالة الحطأ الجسيم وحالة

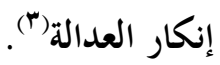

ومن ابرز سمات هذا القانون هو جعل الدولة مسؤولة أمام المتضرر، وتقيم الدعوى عليها مباشرة دون أن يستلزم اللجوء إلى طلب إعادة النظر أو إقامة دعوى المخاصمة بالنسبة للحكم الذي نشأ منه الضرر، فضلاً عن تمييزه بين الخطأ الشخصي لرجال القضاء والذي يرتب المسؤولية الشخصية لهم، والخطأ الوظيفي والذي تكون الدولة مسؤولة عنه(\&). ومن الملاحظ أن القانون المذكور قد اقام المسؤولية على أساس الخطأ، وليس على أساس المخاطر أو تحمل التبعة، وعلى هذا الأساس فإن الدولة لا تكون مسؤولة عن الأضرار التي ترتب عن الأعمال القضائية مالم يكن هناك خطأ من جانب القضاء، مهما كانت الأضرار جسيمة وبليغة، أي لكي يتمكن المتضرر الحصول على هذا التعويض، يجب أن ينظر إلى الخطأ ودرجته، وليس الضرر الذي لم يشتزط فيه درجة معينة من الجسامة، وهذا يعني من الجائز مساءلة الدولة عن الأضرار البسيطة حين تحقق الخطأ الجسيم وإنكار العدالة في حق مرفق القضاء.

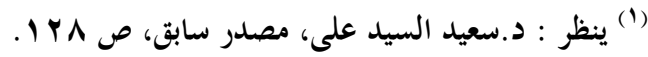

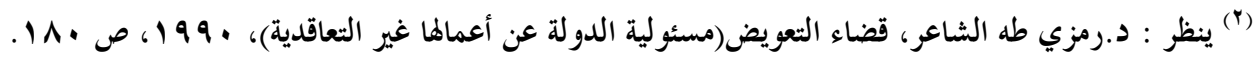

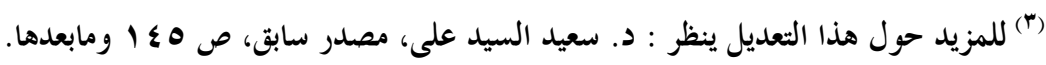

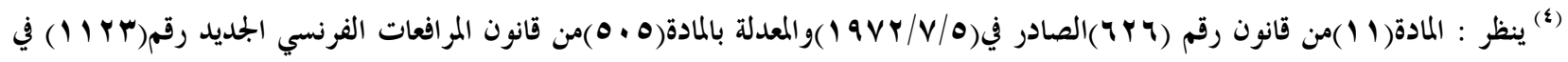

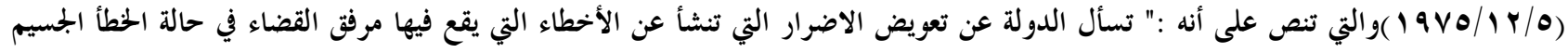
وحالة إنكار العدالة، ويسأل القضاة عن أخطائهم الشخصية، وفي هذه الحالة تضمن الدولة حصول المضرور على تعويض عن الاضرار التي أصابته من 
وعلى الرغم من أن القانون المذكور قد أقام المسؤولية على أساس الحطأ، ألا وانه لم يستبعد تطبيق النصوص التشريعية الأخرى التي قررت المسؤولية على أساس المخاطر أو تحمل التبعة كما في حالتي الحكم بالبراء بعد إلتماس إعادة النظر والحبس الإحتياطي الذي سنبحثه في المبحث الثاني.

ونحن نرى بأن هذا التنوع في الأسس التي تقيم عليها المسؤولية أمر إيجابي، وأن المشرع يهدف بذلك إلى عدم حرمان المتضرر من حصوله على التعويض. هذا بالنسبة لموضوع إلتماس إعادة النظـــــ في القانون الفرنسي، أما عن الوضع في الدول العربية، فإنه نظرا لمراعاة العدالة وتعويض كل متضرر دون النظر إلى مصدر الضرر، ونظراً للتطورات التي حصلت في أحكام المسؤولية، فإنها هي الأخرى إستجابت لما حدث في فرنسا، وعدت طريق إلتماس إعادة الخاكمة من إحدى طرق الطعن غير العادية لإلغاء الحكم السابق بالإدانة، ولكن إختلفوا في إقرار منح حق التعويض للمتضرر.

على الرغم من قيام قانون الإجراءات الجنائية المصري بتنظيم أحكام إعادة النظر، وعدها طريقاً من طرق الطعن الإستثنائية(غير العادية) في الأحكام الصادرة في الجنايات والجنح، إلا أنه لم يرتب علـى الحكم الصادر بالبراءة مسؤولية الدولة عن تعويض الخكوم عليه أو ورثثه من جراء تنفيذ الحكم الصادر بالإدانة الذي ثبت عدم صحته(1)، أي أن نصوص هذا القانون لم تقرر حقاً للمحكوم في طلب التعويض عن الأضرار التي لحقته نتيجة للحكم الحاطيء بالإدانة(؟)، وأنهاقد إكتفت بتقرير نوع من التعويض الأدبي للمحكوم الذي يحكم ببرائته وذلك عن طريق وجوب نشر الحكم الصادر بالبراءة علـى نفقة الحكومة في الجريدة الرسمية بناء على طلب النيابة العامة وفي جريدتين يعينهما صاحب الشأن(ب). يعد موقف المشرع المصري بكصر نطاق التعويض بالأدبي فقط موقفاً منتقداً، لأنه من الأفضل أن يقرر منح التعويض المادي أيضاً تلتزم به الدولة قِبل الخكوم عليه وذلك صيانةً لحق الخكوم عليه ، إذ أن الدعوى الجزائية ترفع بإسم الجموع ولحسابه، وينبغي أن يتحمل هذا الجمهوع ممثلاً في الدولة تبعة تعويض الأضرار المتزتبة إذا تبين بالدليل جوره وبطلانه(؛). ومن هذا المنطلق ذهب قلة من الفقه المصري(ه) إلى أنه ليس هناك مايمنع من أن يككم القضاء العادي بالتعويض للمتضرر في حالة حصول الغكوم

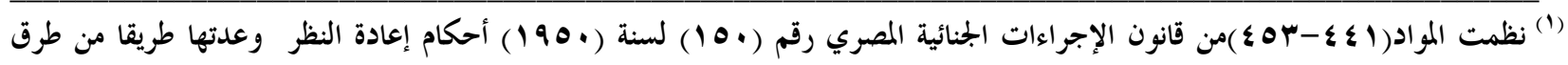

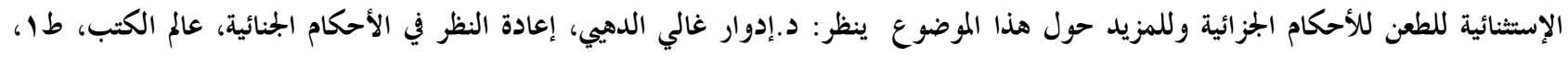

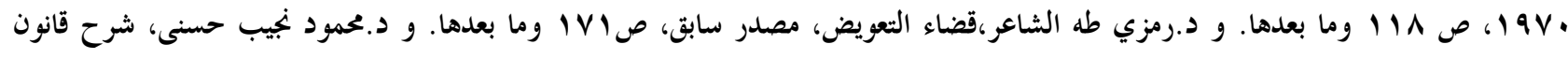

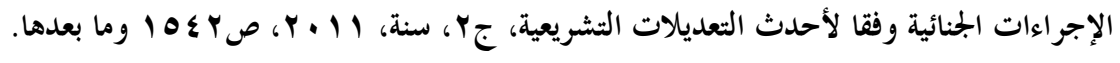

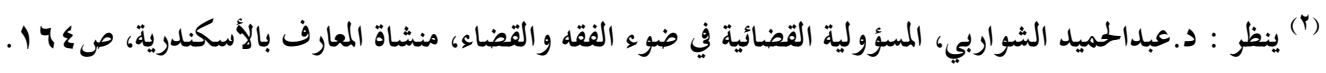

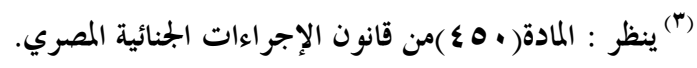

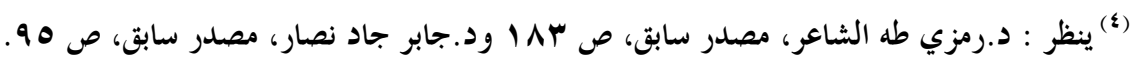

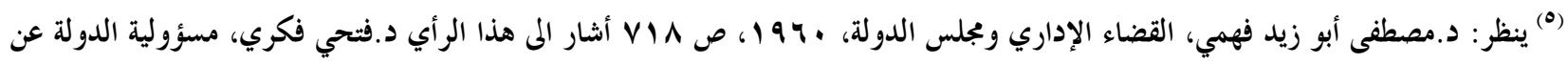


على حكم بالبراءة بنفس الشروط التي أقرها القانون الفرنسي من حيث(عدم وجود الخطأ من جانب الخكوم عليه، والإعتزاف للدولة بحق الرجوع على الأشخاص الذين ضللوا العدالة)، وتبرر رأيها بأنه ليس هناك ما يحتم على القضاء العادي أن يقيد نفسه بالنصوص الواردة في الجموعة المدنية في جميع الأحوال، إلا أن غالبية الفقه المصري ترى بأن هذا السكوت من المشرع لم يكن حائلاً أمام المتضرر بالرجوع على من ساهم بسوء النية في إيقاع القضاء في الخطأ أو بسبب التعسف في الإتهام أو عدم التبصر في إيقاع القاضي في الخطأ مثل الشاهد أوالمخبر أو المشتكي أو الفاعل الحقيقي تطبيقاً للقواعد العامة في القانون المدنى (1)، ويرى البعض(") بأنه إذا كان خطأ الحكم عائد لسبب من أسباب المخاصمة الواردة في قانون المرافعات، فإن ذلك يصلح سبباً لمخاصمة

أما القانون الليبي الذي أجاز هو الأخر طلب إعادة النظر في الأحكام الجنائية(َ)، في الحالات المنصوصة عليها قانوناً و وفق الإجراءات المرسومة لها، إلا أنه يؤخذ عليه أنه لم يقرر تعويضاً للمضرور من الدولة، وأن كل ما قرره المشرع هو أن يرجع المضرور على من تسبب في وقوع الحطأ أو ساهم بسوء النية أو عدم التبصر في إيقاع القاضي في الخطأ وذلك تطبيقا للقواعد العامة في القانون المدني، فضلاً عن وجوب نشر الحكم الصادر بالبراءة على نفقة الحكومة في الجريدة الرسمية بناءً على طلب النيابة العامة وفي جريدتين يعينهما صاحب الشأن(؟). هناك دول عربية أخرى قد حذت حذو المشرع الفرنسي، وذلك من خلال إقرارها بأن تعد إعادة النظر طريقاً لإبطال الحكم السابق بالإدانة من جهة، وطريقاً لمنح التعويض للمحكوم عليه المصرح ببراءته أو لذويه من جهة أخرى. حيث نصت المادة(اسه) امن قانون الإجراءات الجنائية الجزائرية على الحالات التي يسمح بتقديم طلبات إعادة النظر، ونصت المادة(اسه مكرر)على منح الغكوم عليه بالتعويض عن الضرر المادي والمعنوي الذي تسبب فيه حكم الإدانة، ولكن لايمنح هذا التعويض إذا ثبت أن الخكوم عليه نفسه تسبب كلياً أو جزئياً في عدم كشف الواقعة الجديدة أو المستند الجديد في الوقت المناسب. وتتحمل الدولة التعويض الممنوح لضحية الخطأ القضائي أو لذوي حقوقه، فضلاً عن نشر قرار الحكم بالبراءة(•).

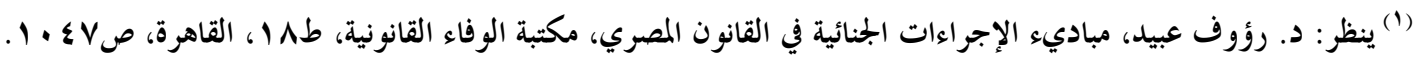

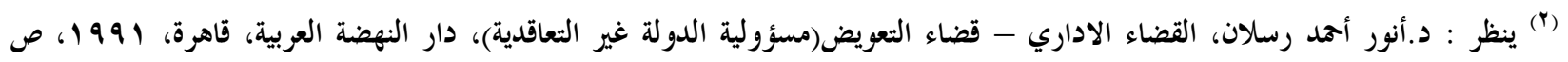

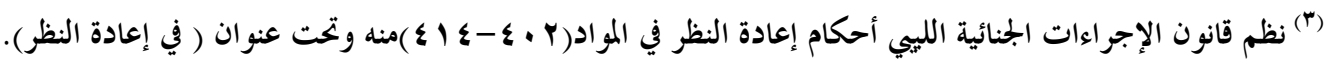

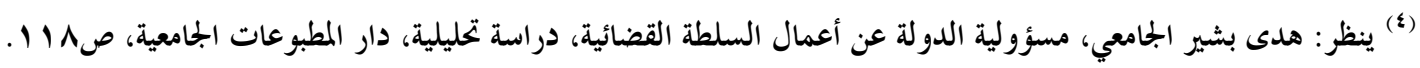

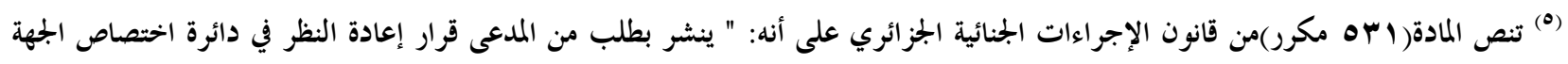

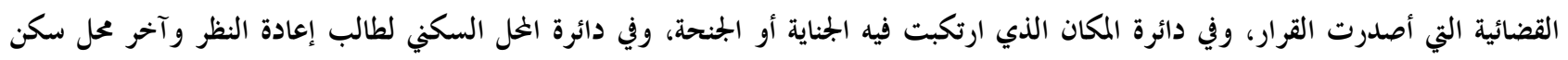


و قد أخذ القانون اللبناني هو الاخر بنظام طلب إعادة الخاكمة، وعده طريقاً استثنائياً للطعن في الأحكام الجنائية لتصحيح الحطأ الوارد في الحكم وبالتالي تحقيق العدالة(1)، ويتزتب على قبول هذا الطعن عدة آثار منها إبطال الحكم السابق بالإدانة

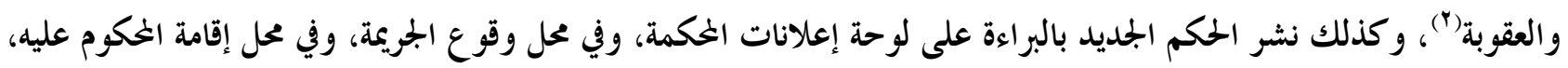

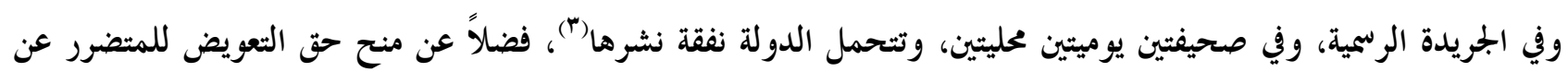

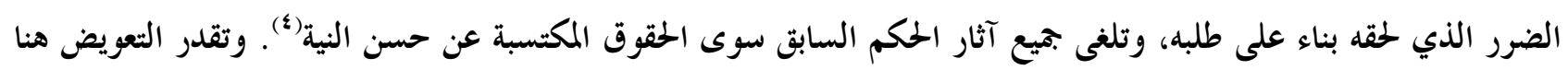

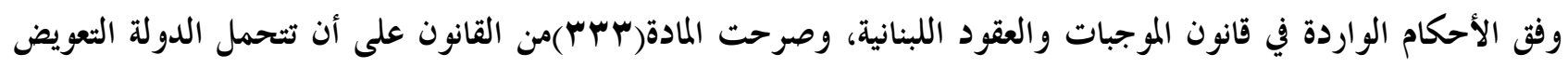
الخكوم به، ولذذا الأخير الرجوع على كل من كان السبب في صدور الحكم السابق.

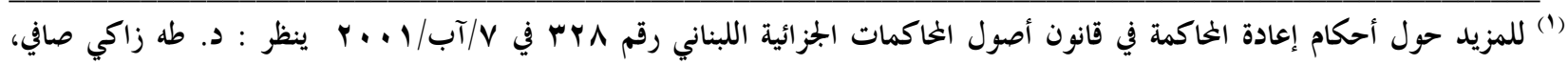

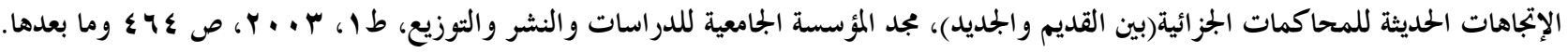

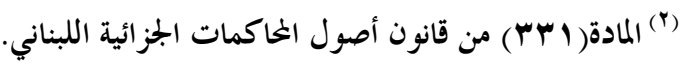

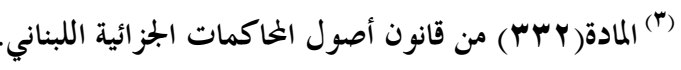

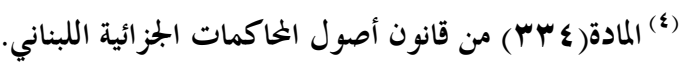




\section{المطلب الثاني \\ مسؤولية المُزيلة عن الأحكام الجنائية التي يككم فيها بالبراءة بعد إعادة الخاكمة في القانون العراقي و والقانون النافذ في إقليم كوردستان}

مهما بلغ سلّم القضاء في الدرجة، تبقى قدرة الإنسان على الوصول إلى الحقيقة والعدالة المطلقة قاصرة، ومن هذا المنطلق تتجه التشريعات الإجر ائية في العديد من الدول إلى القبول بفكرة إعادة الخاكمة كطريق من طرق الطعن (')كوسيلة لرفع الخطأ

الذي أصاب الأحكام الباتة الصادرة بالادانة، وذلك في حالات محددة وبشروط دقيقة(؟). يعد العراق من الدول التي أخذت بهذه الفكرة، ونظمت أحكامها في الباب الرابع من الكتاب الرابع من قانون اصول الخاكمات الجزائية رقم ب ب لسنة ا9V (1، حيث بيّن المشرع الحالات التي يجوز طلب إعادة الخاكمة فيها، والجهة التي تقدم اليها الطلب، والأشخاص الذين لهم الحق في تقديم الطلب، وكيفية البت فيه وإصدار القرار النهائي فيه وأثره على الدعوى(“). رغم أن المشرع العراقي قد أخذ بفكرة إعادة الخاكمة كطريق غير عادي للطعن في الأحكام، إلا أنه لم ينص على حق الخكوم عليه في مطالبة الدولة بتعويض الضرر الذي أصابه من جراء الحكم عليه، وبناء على ذلك فإن الخزينة لاتكون مسؤولة عن تعويض الأضرار التي أصابت الخكوم عليه. ونحن نرى بأن هذا السكوت من المشرع لايحول دون مطالبة المتضرر التعويض من الشاهد أو المبلغ أو المتسبب، تطبيقاً للقواعد العامة في المسؤولية التقصيرية، فضلاً عن إمكانية مخاصمة القاضي أو الهيئة التي أصدرت الحكم إذا توافرت حالات الشكوى من القضاة. ولكن هذه الطريقة في منح التعويض للمتضرر لم تكن ناجعة كونها محفوف بعساويء لايمكن إغفالها منها، أولا : أن القانون المدني قد أشتزط للحكم على شخص بالتعويض أن يكون مخطئً، ومن الختم على المدعي أن يثبت صدور هذا الخطأ منه، فضلاً عن توفر الأركان الأخرى للمسؤولية من الضرر والعلاقة السببية بينهما، وهذا ليس بالأمر الهين له. ثانياً : أن دعوى شكوى

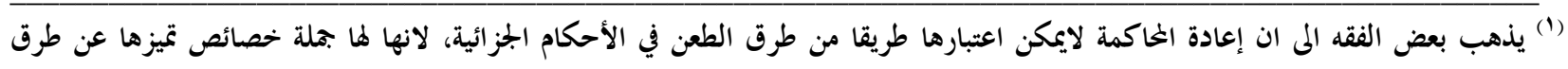

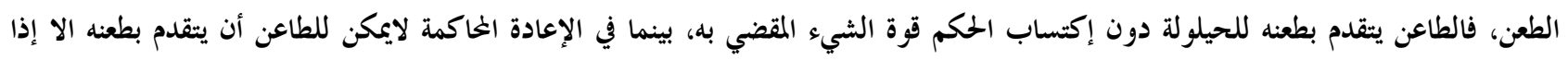

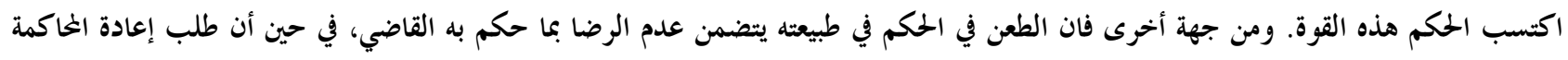

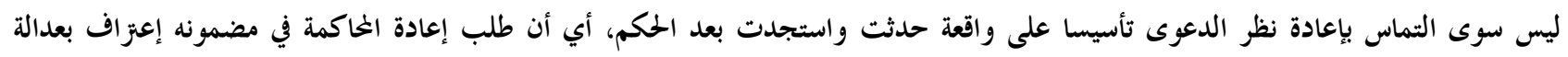

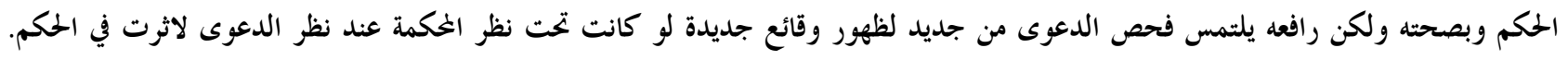

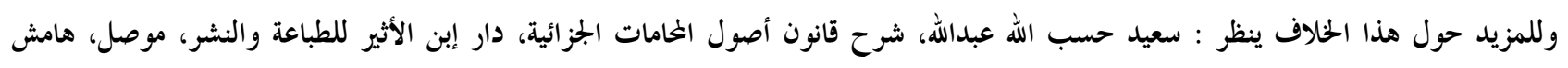

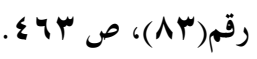

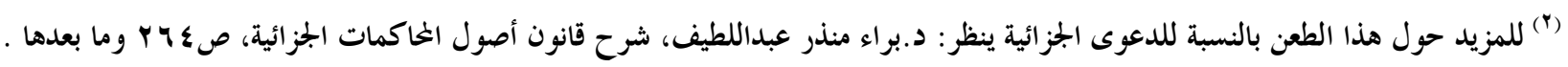

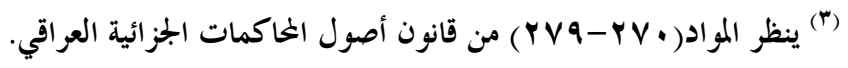


من القضاة من الدعاوى المصبوغة بصبغة الشكلية وبحاجة المى إستيفاء عدة شروط لابد من تحققها وبعكسها فإنها معرضة للرد، وهذا يشكل نوعاً من الإستحالة في العثور على تطبيق قضائي لها. ثالثاً : في كثير من الحالات التي تقبل فيها طلب الاعادة الخاكمة لايكون سبب قبول الطلب راجعاً إلى صدور الخطأ من الخكمة بل يكون السبب هو التعسف في تقدير الأدلة أوسوء تقديرها لها، وفي هذه الحالة فإن الحطأ لم يكن وارداً حتى يكون الحكم قابلاً للتصحيح، لذا فإن منح حق التعويض للمتضرر هو الجزاء الأكثر عدلاً لإزالة تلك الأضرار، فضلاً عن ذلك أن القانون قد أعطى سلطة تقديرية واسعة للمحكمة في تقدير الدليل من جهة وحرية تكوين القناعة من جهة أخرى مما يستبعد فكرة وقوعها في الخطأ، وقد يكون هذا التقدير مصدقاً بقرار الخكمة العليا ولكن حين ظهور حقيقة الواقعة وثبوت كون الخكمة لم تكن صائبة أو محقة في تقدير الدليل أو تعسفها فيه، لم يكن هناك اية طريقة سوى تعويض المتضرر مطلقاً دون النظر إلى مصدر الضرر("). رابعاً: قد تكون طريقة التعويض أمام المتضرر مسدودة رغم حصوله على التعويض وذلك حينما كان المسؤول معسراً، مما يصعب عليه إن لم يكن مستحيلاً الإستفادة من حكم الخكمة لأنه قيل لا خير في حكم لانفاذ له.

ولإبعاد حدوث مثل هذه النتائج التي تحول دون تعويض المتضرر من جهة، ولكي تكون تشريعاتنا منسجمة والتطورات التي طرأت على احكام المسؤولية، ومراعاة للعدالة والبر الإجتماعي والخكوم عليه من جهة أخرى، لذا فإن المشرع العراقي مطالب بأن يسد هذا النقص أسوة بما فعلثه بقية المشرعين وأن ينص على حق المتضرر من الحصول على التعويض، وأن تجعل الدولة مسؤولة عنه بمجرد إثبات البراءة سواء بتعديل أحكام قانون أصول الخاكمات الجزائية النافذ بإضافة مواد تقرر هذه الجوانب أو بإصدار تشريع مستقل تنظم فيه كافة الأحكام المتعلقة بمسؤولية الحزينة عن أعمال السلطة القضائية(؟). وتقيم المسؤولية هنا على أساس الضرر حتى ولو لم يكن هناك خطأ من المرفق، وأساس هذا القول هو أن الدولة مادامت تلقت على عاتقها مهمة تحقيق فض المنازعات وإقامة العدل بين المواطنين، هادفة من ورائها تحقيق مصلحة عامة تتمثل بنشر الطمأنينة والسلام والإستقرار في الجتمع. وقد يحدث بأن يصاب البعض بأضرار حينما كانت الدولة منشغلة بتحقيق تلك المصلحة رغم عدم وجود الخطأ من جانبه، مثل ضرورة إتخاذ إجراءات التحقيق الأصولية بكق الشخص الذي يوجد الشك في

(1) للمزيد حول سلطة القاضي في تقدير الأدلة، ينظر : د.فاضل زيدان محمد، سلطة القاضي الجنائي في تقدير الأدلة، دار الثقافة للنشر والتوزيع،

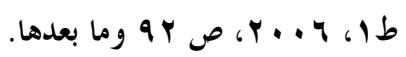
(r) يتجه الجلس النواب العراقي وضمن التوجهات الرامية لإنصاف المظلومين ومن وقع بحقهم إجحاف، المى تشريع قانون بإسم(قانون تعويض

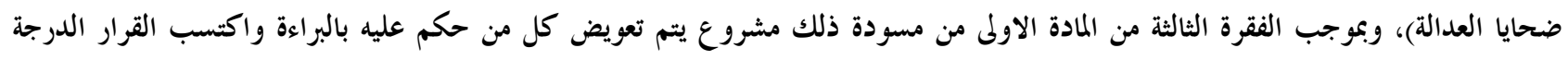

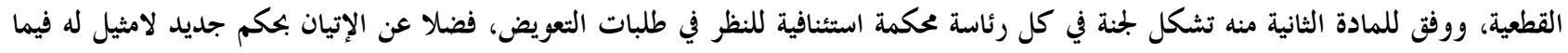

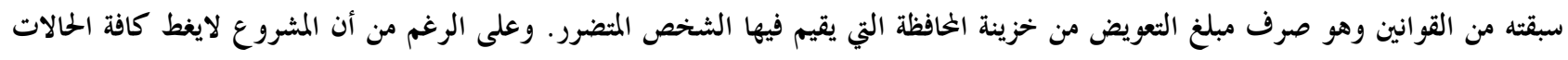

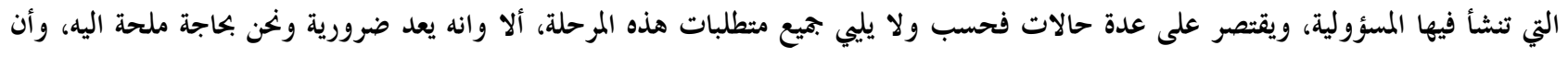

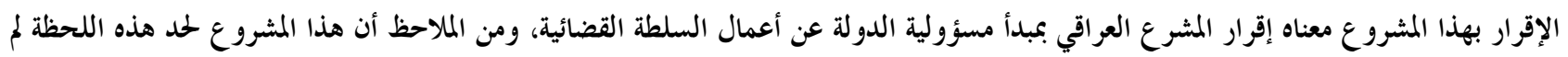


تورطه في إحدى الجرائم الإرهابية مثلاً، حيث تستهدف الجهات التحقيقية من إتخاذ مثل هذه الإجراءات التغلب على العناصر التي تزعزع الإستقرار في الدولة، لذا فان تسليمهم للسلطات ومعاقبتهم هو الهدف المنشود من الإجراءات، ولكن قد لا تجري الرياح بما تشتهي السفن، أي لايكون جميع من أتخذت الإجراءات ضدهم عناصر سيئة أو عندهم خطورة على الجختمع، لذا فان العدالة تقتضي بأن يتحمل هؤلاء الأشخاص وزر عمل القضاء رغم وجود ضرر مادي ومعنوي بحقهم ومن المفروض أن تعوضهم الدولة، وتسعفنا في ذلك نصوص قانون إصلاح النظام القانوني رقم هب لسنة I IVV حيث تقيم هي الأخرى المسؤولية المدنية على فكرة الضرر وحده (1). أما في إقليم كوردستان وإنطلاقاً من المباديء الديموقراطية وحماية الحقوق والحريات العامة وإيماناً بلزوم تعويض المتضرر من الأعمال القضائية، فقد بادر برلمان إقليم كوردستان بتشريع قانون مكافحة الإرهاب رقم ب لسنة ج ×. . . وقانون تعويض الموقوفين والخكومين عند البراءة والإفراج رقم 10 لسنة ـ 1 ـ و اللذين قد تضمنا أحكاماً تعطي الحق للمتهم الذي يتم براءته أو يفرج عنه أو يثبت توقيفه تعسفياً، أن يطالب التعويض من خزينة الإقليم عن الأضرار المادية والمعنوية التي لحقت به(؟). وعند التمعن في أحكام ذلك القانون يجد بأن القانون قد وفر حماية قانونية للمتضرر والمتمثل بحق طلب التعويض من خزانة الاقليم، دون لزوم صدور الخطأ من القضاء.

يعد بكق موقف المشرع الكوردستاني بمنح الحق للمتضرر بمطالبة التعويض حين حصوله على حكم بالبراءة أو الإفراج أو ثبوت وقوع التعسف في توقيفه، موقفاً تشريعياً متميزاً، حيث يعطي التعويض للمتضرر دون أن يكلفه بإثبات الخطأ من جانب أحد، وأنه قد جعلت الحزينة مسؤولة عن هذا التعويض. وهذا الحكم هو الذي يوافق العدالة، وينسجم والبر الإجتماعي والشخص الذي يجعل القضاء ملجأ له في كل منازعة يلجأ اليه مادام أنه على علم بأنه سوف يعوض عن كل خسارة أصابته بصرف النظر عن مصدر الضرر، ولولا مثل هذا الحكم لأثرت ذلك على زعزعة الثقة العامة بالقضاء، ويجعل القضاء ساحة للكيد و وسيلة بيد أصحاب المكيدة للنيل من الآخرين كونهم على علم بأن أسوء النتائج التي تتحملونها من خلال عملهم هذا هو بطلان العمل دون أن يتحمل أي وزر من جرائه، وهذه النتيجة لايقبلها العقل السليم ويأباها المثرع(“).

(1) ينظر : سيروان رؤوف علي، التعسف القضائي والمسؤولية المدنية الناجمة عنه، دراسة تحليلية، رسالة ماجستير قدمت الى كلية القانون والسياسة

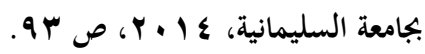

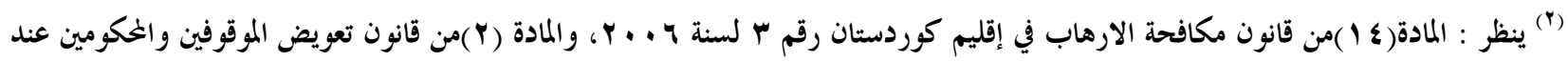

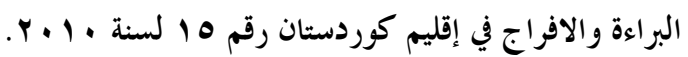

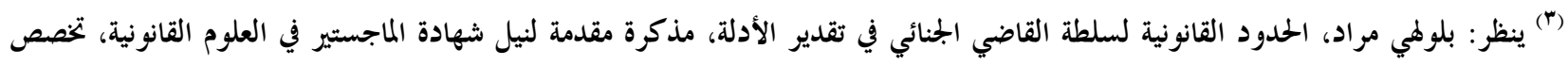

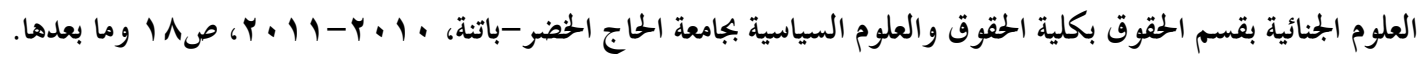




\section{المبحث الثاني}

\section{مسؤولية المزينة عن أضرار التوقيف (الحبس الإحتياطي)}

نتناول في هذا المبحث المسؤلية المدنية للخزينة العامة عن الأضرار التي تزتب على التوقيف في مطلبين ،خصص الأول لموقف القوانين المقارنة من هذه المسؤولية، فيما ندرس في الثاني موقف المشرع العر اقي والكوردستاني منها.

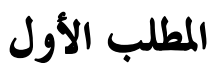

\section{مسؤولية الحزينة عن أضرار التوقيف في القوانين المقارنة}

يعد التوقيف(1) من أخطر الإجراءات التي تتخذها الخكمة لمساسه بالحرية الشخصية للمتهم التي كفلها الدستور، فهو ليس

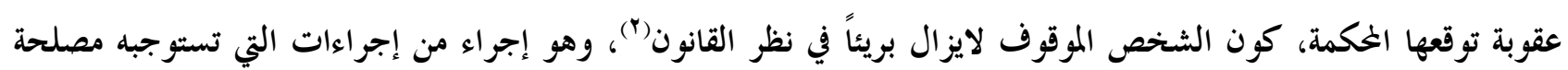

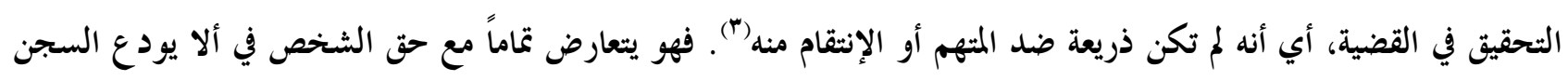
إلا تنفيذاً لحكم صادر بإدانته من القضاء (\$). قد يكون هذا الإجراء مطلوباً، بل ضرورياً، إذا اقتضته مصلحة التحقيق، وذلك منعاً لتأثير المتهم في الشهود، أو تهديد

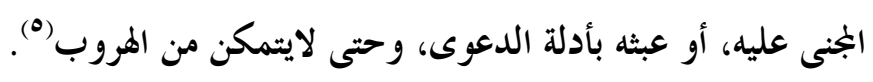

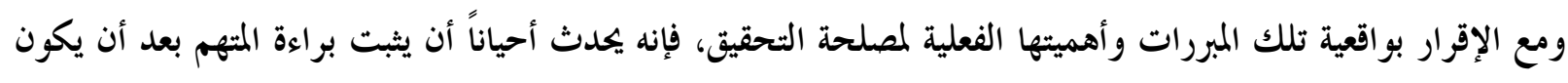

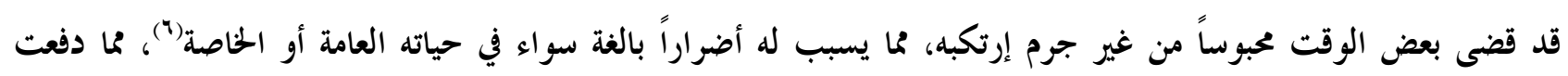

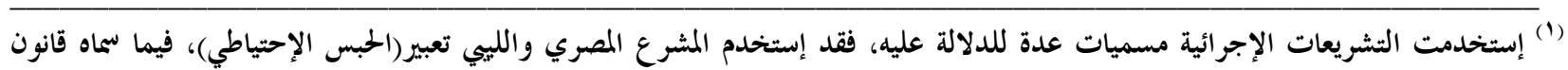

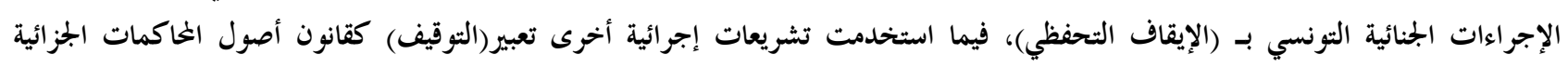

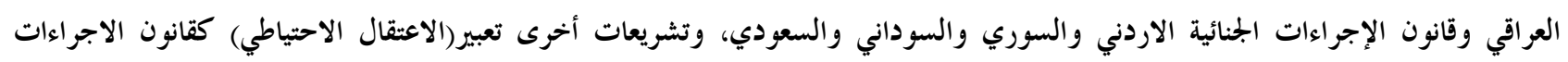

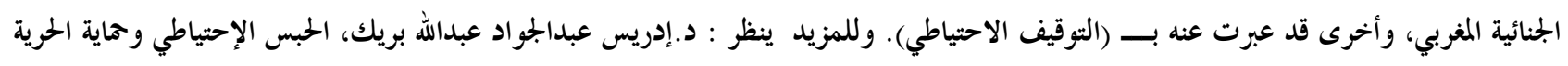

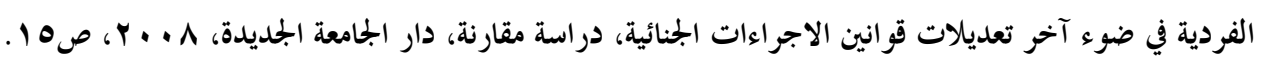

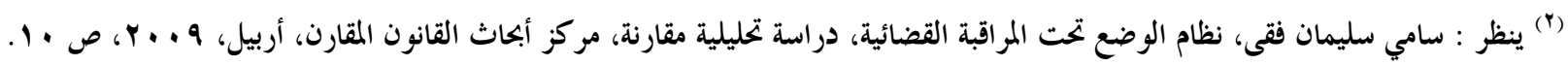

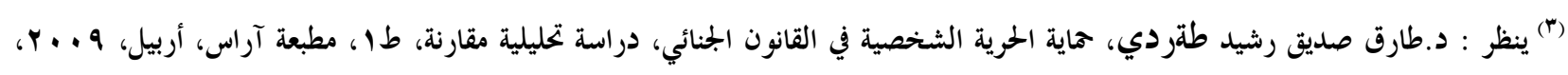

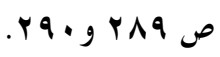

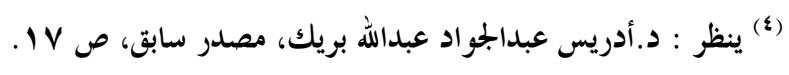

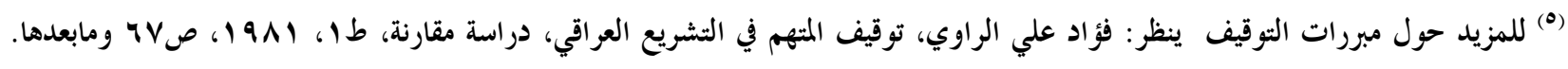

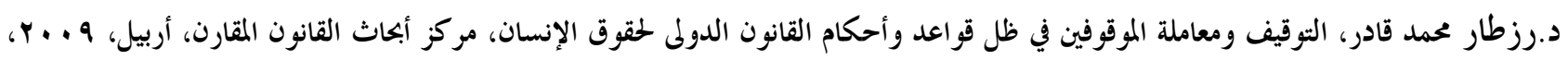
ص م 10 و وما بعدها. 
البلدان خارجياً(1) داخلياً(r) أن تحاول جاهداً لإيجاد نقطة توازن بين مصلحة الجُتمع في حماية أمنه، من خلال إجراءات التحقيق

ومنها التوقيف، وبين حماية الحرية الشخصية من الإجر اءات التي تتجه إلى تقييدها؟َ).

قبل بيان موقف قوانين محل الدراسة إزاء هذا الإجراء والمسؤولية المدنية الناجة عنه، نجد بأن الفقه منقسم المى إتجاهين، إتجاه أنكر منح حق التعويض للمتهم عن الحبس الإحتياطي ولو كانت الأضرار جسيمة، وإتجاه قد أقر بمنح هذا التعويض حين تحقق شروطه، وأن لكليهما حجج ومبررات، وأن هذا الإختلاف في الفقه هو السبب في إعتناق الدول المختلفة بالإتجاه الذي يوائم

سياسته التشريعية حين معالجة الحبس الإحتياطي (\&). كان القضاء الفرنسي يرفض دائماً تقرير المسؤولية عن أضرار التوقيف(الحبس الإحتياطي)، وذلك سيراً مع موقفه المستقر في عدم مسؤولية الدولة عن أعمال القضاء في غير حالتي البراءة نتيجة لإعادة النظر وقبول دعوى المخاصمة، ثم حدث تحول في موقفه حينما أصدرت محكمة باريس حكمها في 10 اكتوبر 999 اوالتي أقرت بمسؤولية الدولة عن الحبس الإحتياطي (•). وعلى الرغم من إقرار القضاء الفرنسي للمبدأ إلا أنه كان متزدداً في تقرير التعويض فعلاً للمضرور، لأنه يطبق أحكام القانون المدني التي تنطلب الحطأ، ونتيجة لهذا الإشتزاط إنتهى القضاء الفرنسي إلى عدم منح التعويض في دعاوى المقامة على الدولة لإفتقارها لر كن الخطأُ). ولمواجهة هذه الحالات فقد تدخل المشرع الفرنسي بمقتضى قانون صدر في IV يوليو • (9V، حيث قرر مسؤولية الدولة بالتعويض عن الأضرار التي تصيب الأفراد بسبب قرارات الحبس الاحتياطي في حالة تقرير سلطة التحقيق أنه لاوجه لإقامة

(1) على المستوى الدولى فإن كثيرا من المواثيق الدولية قد نصت على حق الشخص الذي يناله إجراء الحبس الإحتياطي في الحصول على التعويض من ذلك وثيقة العهد الدولى

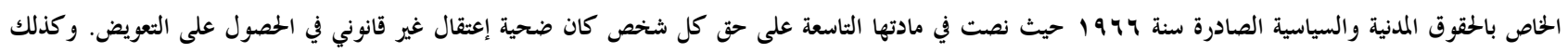

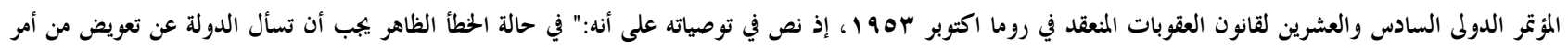

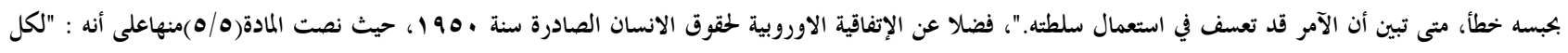

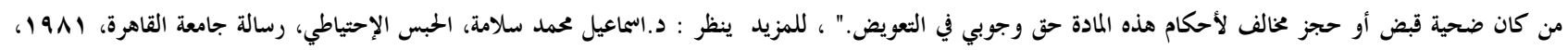

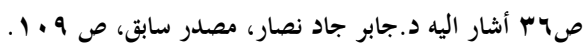
() من الدول التي اقرت بالتعويض عن التوقيف(الحبس الاحتياطي) وبتشريعات خاصة هي هولندا، سويسرا، بلجيكا، السويد، البرتغال، الدانمارك،

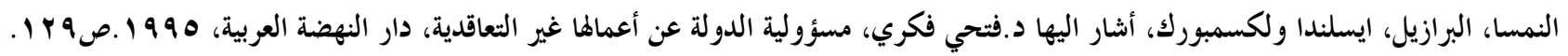

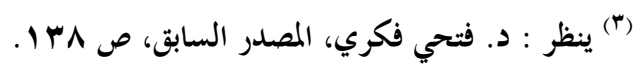

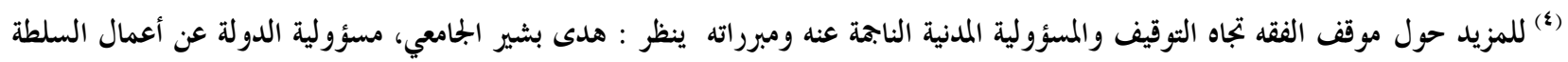

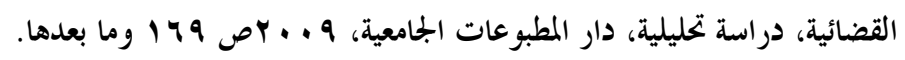

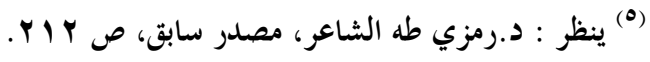

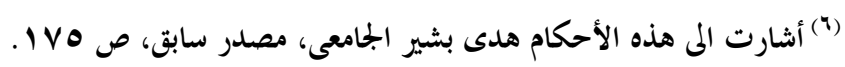


الدعوى، أو حكمت الخكمة بالبراءة وذلك كله إذا كان الضرر إستثنائيا(').وبموجب هذا القانون،لايلزم المضرور بإثبات خطأ القاضي الذي أصدر قرار التوقيف، حيث يكفي أن يكون الضرر إستثنائياً حتى ولو لم يوجد خطأ، وتتحمل الدولة التعويض الذي يحكم به للمضرور، ولها الرجوع على كل من تسبب في توقيفه كالمبلِغ بسوء النية أو شاهد الزور(؟). أن القانون المذكور قد حدد كيفية الحصول على التعويض، والثروط المطلوبة لإستجابته، فضلاً عن تحديد الجهة التي تنظر في الطلب، حيث يتبين لنا من خلال التعمق في تلك الأحكام بأن هذا التعويض يكون بالطلب دون الدعوى والذي يقدم إلى اللجنة المكونة من ثلاث مستشارين من محكمة النقض، حتى وأن المشرع لم يشتزط في عمل اللجنة مراعاة الأصول والأحكام الواجبة تطبيقها في العمل القضائي، بالنسبة للتسبيب و السلطة التقديرية الممنوحة لها بالإضافة المى سلطتها في تقدير التعويض دون الرجوع إلى آراء الحبراء حتى وأن قراراتها باتة وغير قابلة للطعن، وهذه السمات تعد من أبرز ما يعرف به العمل القضائي ويميزه عن غيره من الأعمال (ب). أن مواجهة المشرع الفرنسي للأضرار الناجمة عن التوقيف المؤقت، ومعالجته بذلك الأسلوب، كان محل نقد من الفقه من جهة والإدانة من قبل الخكمة الأوروبية لحقوق الإنسان من جهة أخرى، مما دفع المشرع الفرنسي إلى إجراء تعديلات جذرية على

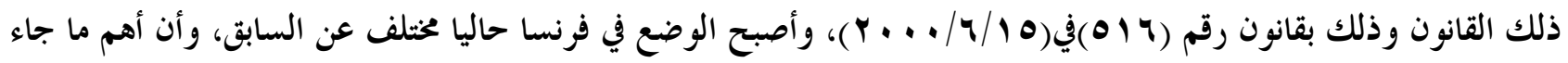
في القانون الجديد هو نزع سلطة التوقيف من قاضي التحقيق وإعطائها لجهة قضائية جديدة وهي قاضي الحريات والتوقيف، فضلاً عن تعديل الأحكام الموضوعية المتعلقة بالتعويض وتخفيف شروطه(\&). ويرى بعض الفقه(ه) بأن إقرار المشرع الفرنسي بمنح التعويض للمتضرر عن الحبس الإحتياطي بتشريع مستقل، لايمول دون إمكانه اللجوء إلى قواعد وأحكام قانون المرافعات

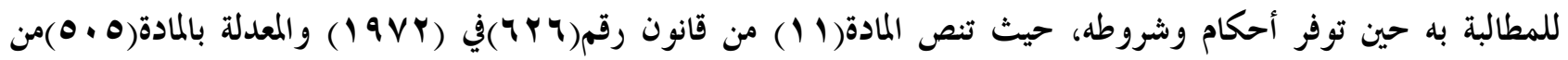

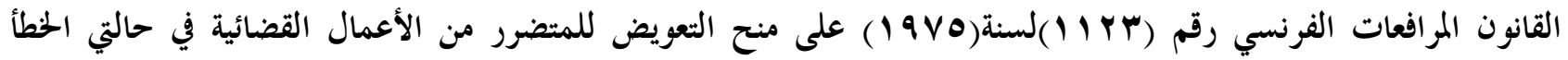
الجسيم وإنكار العدالة.

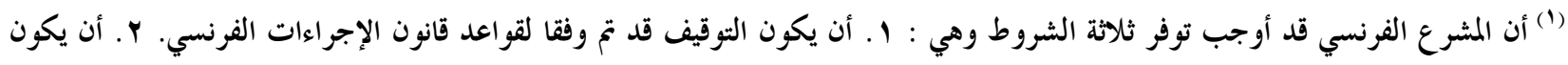

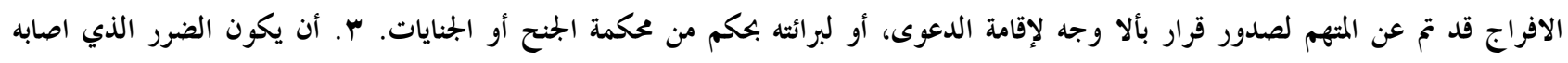

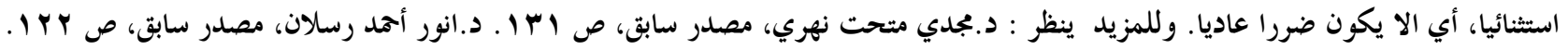

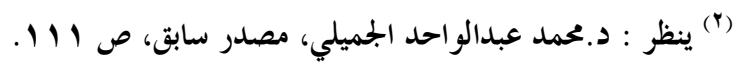

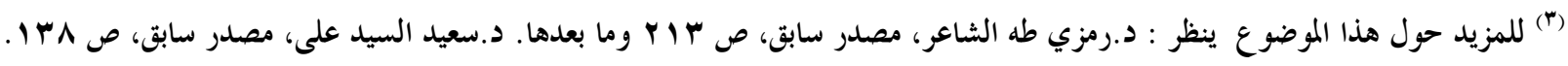

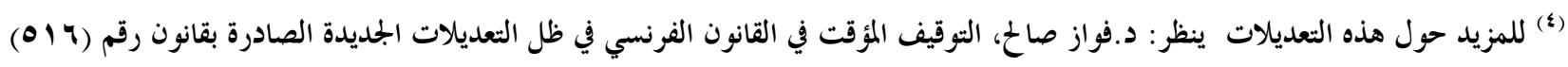

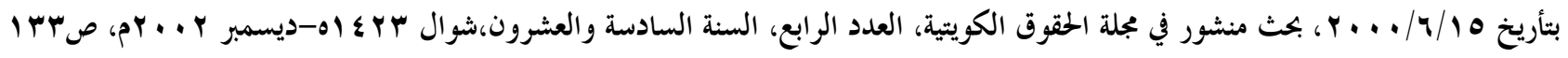

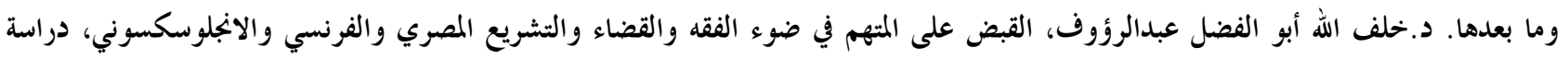

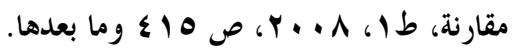


أما بالنسبة لموقف المثرع المصري تجاه التوقيف والتعويض عنه، نجد بأنه لايوجد قانون خاص أو نصوص خحاصة مثلما ما ورد في القانون الفرنسي، إلا أن البعض(1) يرى بأن روح الدستور المصري سنة (9VI I ) تنطلب صدور مثل تلك النصوص التي تعطي حق التعويض لمن تضرر نتيجة الحبس الإحتياطي، وييرر موقفه بأن المادة(OV)منه تنص على أنه :"كل إعثداء على الحرية الشخصية أو حرمة الحياة الحاصة للمواطنين وغيرها من الحقوق والحريات العامة التي يكفلها الدستور والقانون جريمة لا تسقط الدعوى الجنائية ولا المدنية الناشئة عنها بالتقادم، وتكفل الدولة تعويضاً عادلاً لمن وقع عليه الاعتداء."، ويرى بأن هذا النص عام ويشمل مايقع من موظفي الدولة كافة، وأن التعويض يقع على عاتق الدولة وليس على الموظف، ألا أن البعض يرى بأن المشرع المصري يفضل الوقوف عند قاعدة عدم مسؤولية الدولة عن أعمال السلطة القضائية، حفاظاً على المال العام بسبب التعويضات التي يطالب يها المتضررين من أعماله(؟). وبعد مرور أكثر من نصف قرن على صدور قانون الإجراءات الجنائية المصري، وبفضل التطورات التي حصلت في مجال المسؤولية والإقرار بالمسؤولية عن الأعمال القضائية، وبسبب الإنتقادات الموجهة للتشريع المصري وعدم مواكبته للعصر، تدخل المشرع المصري وذلك عن طريق تعديل بعض أحكام قانون الإجراءات الجنائية بقانون

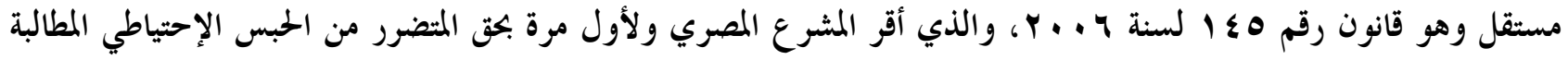

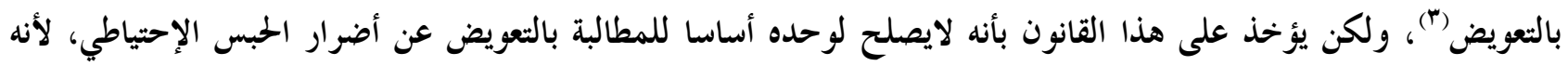
ينقصه تنظيم أحكام هذا التعويض وكيفية إستحصاله والوسائل التي تكفل تنفيذه فضلاً عن إفتقاره لبيان الشروط والإجراءات التي تتخذ بشأن الطلب، وتعين الجهة التي تنظر الطلب، بل أحال المشرع تنظيم كل هذه الحالات بتشريع مستقل والذي لم ير

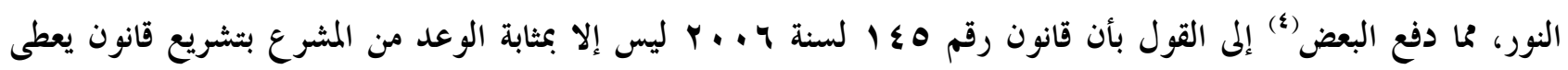
بالتعويض المادي عن الحبس الإحتياطي.

وبعد إجراء الإستفتاء على الدستور المصري الجديد عام r I ب ودخوله حيز التنفيذ، نجد بأن التوجه نحو الإقرار بعبدأ المسؤولية عن الأعمال القضائية صار من المسلمات، حيث ورد في المادة(هب)منه على أنسـه:" فيما عدا حالة التلبس، لا يجوز القبض على أحد ولا تفتيشه ولا حبسه ولا منعه من التنقل ولا تقييد حريته بأي قيد إلا بأمر قضائي مسبب يستلزمه التحقيق ويجب أن يبلغ كل من تقيد حريته بأسباب ذلك كتابة خلال اثنتي عشرة ساعة، وأن يقدم إلى سلطة التحقيق خلال أربع وعشرين ساعة من وقت تقييد حريته، ولا يجرى التحقيق معه إلا فى حضور محاميه، فإن لم يكن ندب له محام ولكل من تقيد

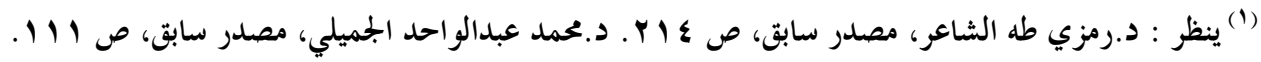

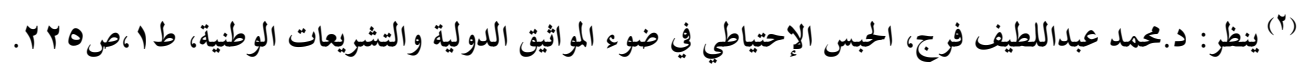

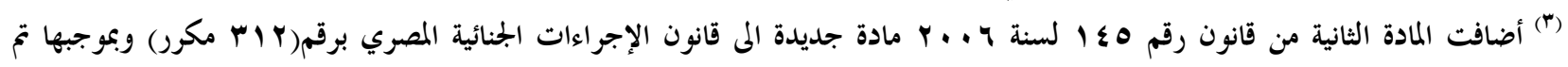

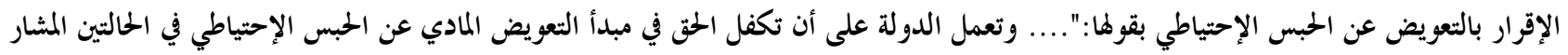

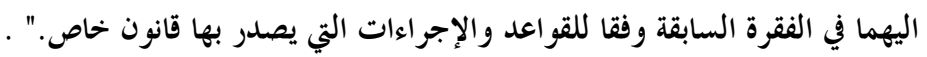

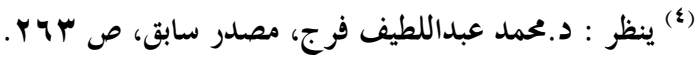


حريته، ولغيره، حق النظلم أمام القضاء من ذلك الإجراء والفصل فيه خلال أسبوع، وإلا وجب الإفراج حتماً، وينظم القانون أحكام الحبس الاحتياطى ومدته وأسبابه، وحالات إستحقاق التعويض وأدائه عن الحبس الاحتياطى، أو عن تنفيذ عقوبة صدر حكم بات بإلغاء الحكم المنفذ بموجبه.". وكذلك ورد في المادة (•^) منه على أنه:" كل إعتداء على أي من الحقوق والحريات المكفولة فى الدستور جريمة لا تسقط عنها الدعوى الجنائية ولا المدنية بالتقادم، وتكفل الدولة تعويضاً عادلاً لمن وقع عليها الإعتداء وللمضرور إقامة الدعوى الجنائية عنها بالطريق المباشروللمجلس القومي لحقوق الإنسان إبلاغ النيابة العامة عن أي إنتهاك لهذه الحقوق، وله أن يتدخل فى الدعوى المدنية منضماً إلى المضرور، وأن يطعن لمصلحته فى الأحكام.". ورغم هذا الإقرار في الدستور والذي هو في رأس الهرم التشريعي، إلا أنه لايكفي لإسعاف المتضرر من الحصول على التعويض كون المعالجة معيبة بسبب إفتقارها لبيان الطرق والاجراءات التي سيتخذها المتضرر في سبيل حصوله على التعويض والجهة التي يقدم ليها الطلب وما إلى آخره من الأحكام المتعلقة بالتعويض، فضلاً عن أن هذه النصوص ليست إلا تكرارا لما شرعت بقانون رقم هـ 1 لسنة

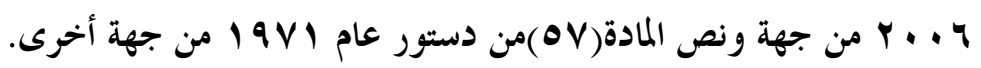

أما موقف القانون الليبي فإنه هو الآخر لم يعط المتضرر حق طلب التعويض جراء حبسه إحتياطياً من الأضرار التي لحقته، وأنه لم يعرف موضوع منح التعويض للمتضرر من الحبس الإحتياطي، حيث نظم الفصل الثامن من قانون الإجراءات الجنائية الليبي الأحكام التفصيلية المتعلقة بالحبس الإحتياطي(') دون الحوض في موضوع حق الخبوس إحتياطياً من طلب التعويض جراء الاضرار الناجمة عنه. ونظراً لمرور أكثر من نصف قرن على صدور القانون المذكور فإِن المشرع الليب وإستجابة لما طرأ على لي أحكام المسؤولية من التطور، قد بادر إلى تعديل بعض أحكام الحبس الإحتياطي وذلك بقانون رقم(ب) لسنة (ب . . ب) والصادر

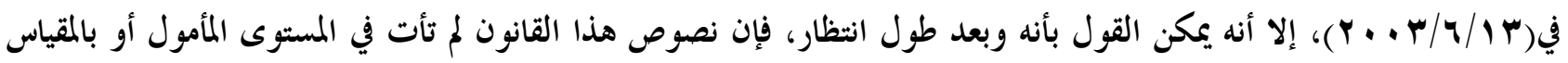
المطلوب إستناداً إلى الإتفاقيات الدولية ذات العلاقة بحقوق الإنسان، وأن ما يتضمنه التعديل لاعلاقة له بموضوع التعويض عن الحبس الإحتياطي. لم يكن موقف التشريع الجزائري مختلفاً عن نظيريه المصري والليبي، حيث كانت نصوص قانون الإجراءات الجزائية الجزائري خالية من الإشارة المى منح المتضرر حق مطالبة بالتعويض المادي جراء حبسه إحتياطياً، رغم صراحة نص المادة(9 §)من الدستور وذلك بتحميل الدولة عبء الضرر الناجم عن أعمال السلطة القضائية(؟). وكنتيجة للإنتقادات الموجهة إلى أحكام قانون الإجراءات الجزائية، وخاصة ماتعلق بأحكام الحبس الإحتياطي، فإن المشرع الجزائري يعمد من حين لآخر لإجراء بعض التعديلات على تلك الأحكام، مضيفاً في كل مرة مزيداً من الضمانات حماية لحق الحرية، والتي تعد من أسىى الحقوق الدستورية،

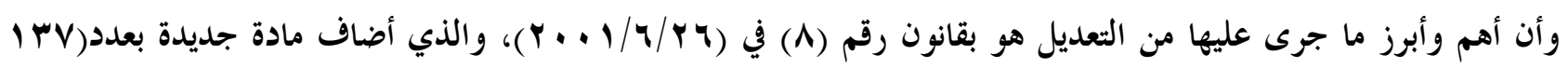

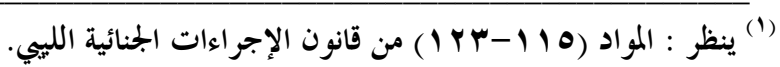

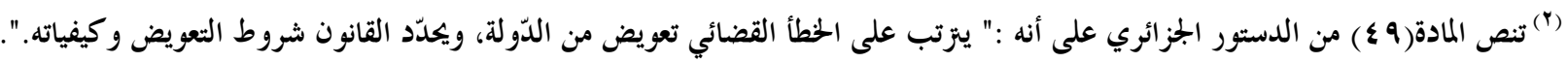


مكرر) إليه، وبموجبها يتمكن المتضرر من الحبس الإحتياطي مطالبة المزينة بالتعويض حين صدور قرار نهائي بأن لاوجه للمتابعة

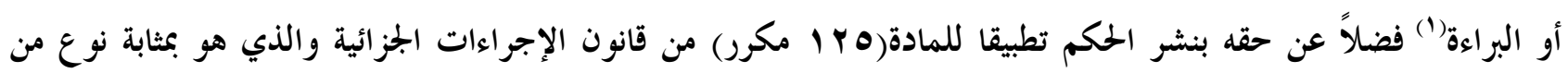

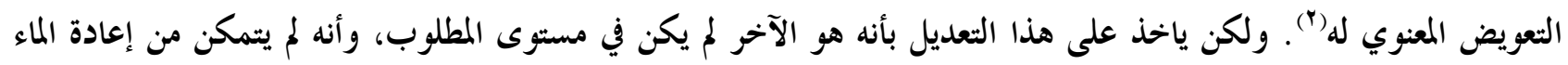

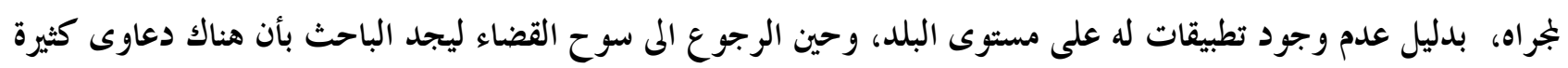
لم تحسم بعد ولم يقدر حق التعويض للمثضرر، مما دفع الفقه إلى المطالبة بتخفيف شروط التعويض لكي لكئل لايكون التعديل مثل ماسبقته من التعديلات مجرد حبر على الورق (").

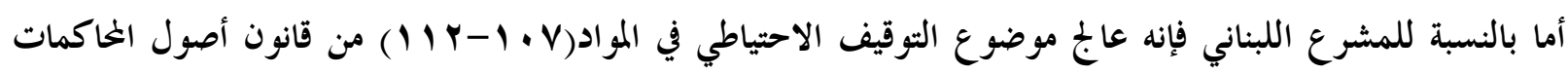

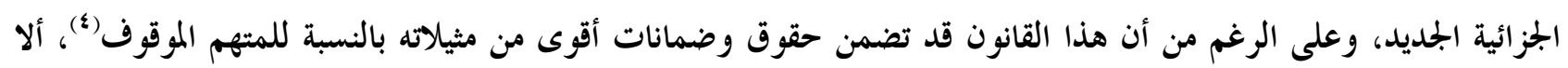

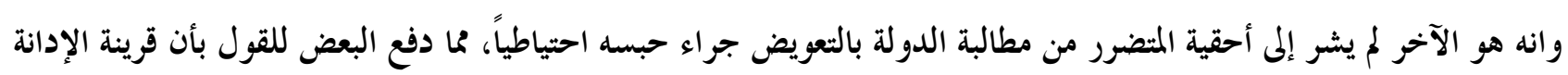

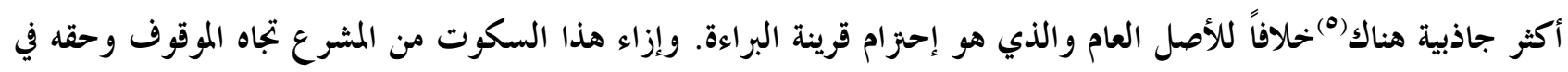
التعويض، فإن هناك قواعد يمكن للمتضرر اللجوء اليها للمطالبة بالتعويض وأن تؤسس دعواه عليها، حيث أوجبت المادة

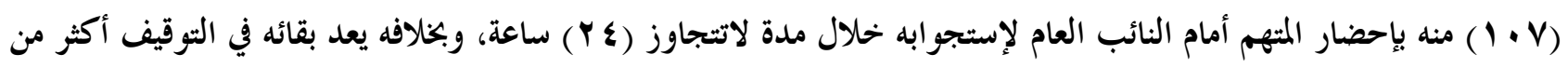

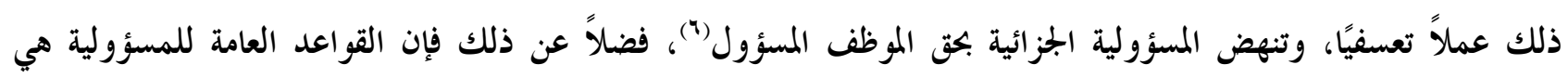

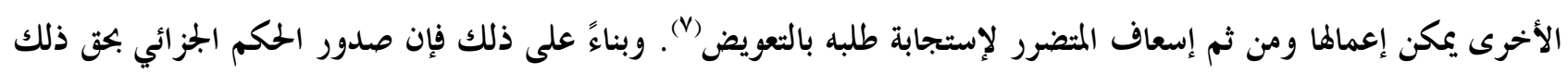

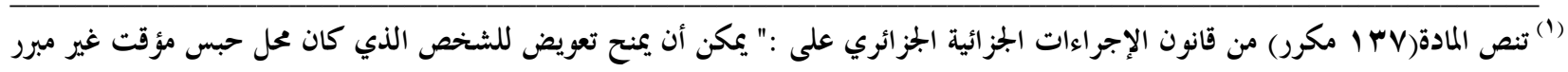

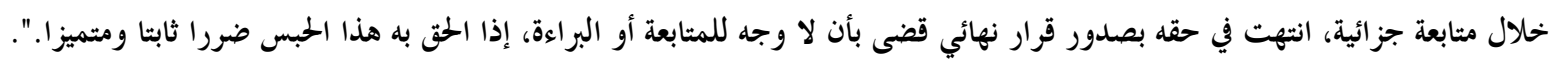

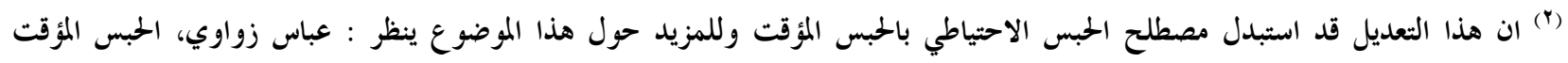

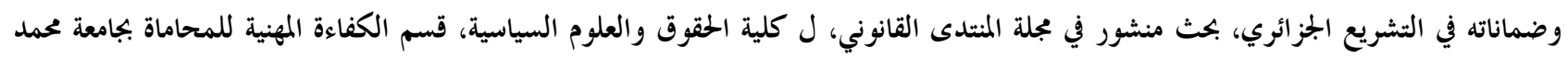

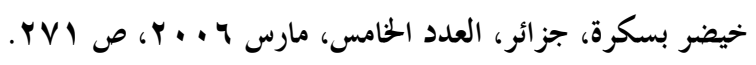

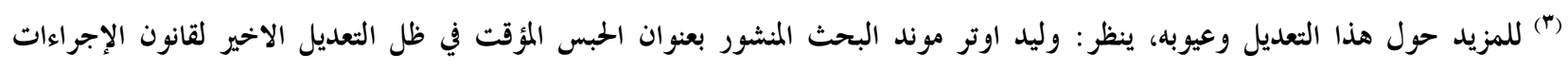

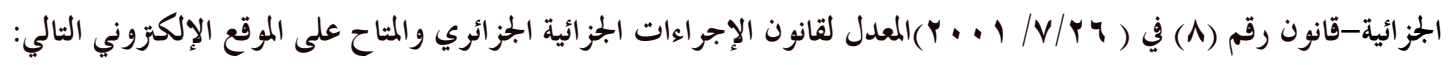
/2014 \&/r rlast visit هrorrhttp://montada.echoroukonline.com/showthread.php?t=

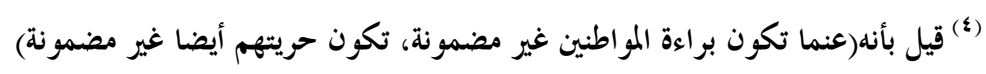

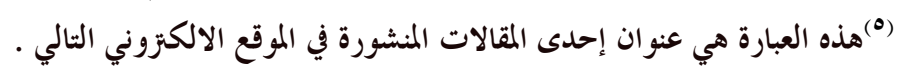
. Last visit: 30/4/2014 www.legal-agenda.com

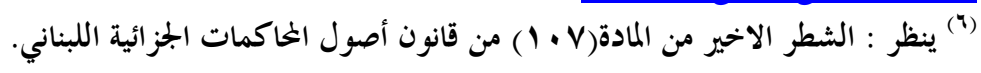

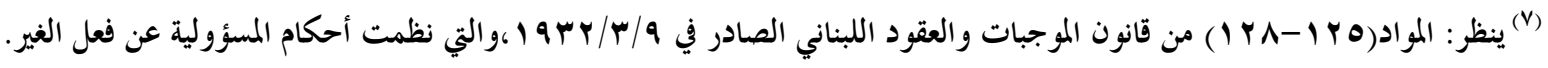


الموظف يعطى الحقى للمتضرر مقاضاته أمام الخاكم المدنية ومطالبته بالتعويض جراء الأضرار التي لحقته(1)، كل ذلك على أساس عمل غير مشروع الذي أرتكبه الموظف أثناء تأدية عمله، وفي هذه الحالة له الحق في إختصام الخزينة كونها مسؤولة عن خطأ

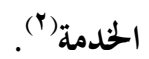

\section{المطلب الداني}

\section{مسؤولية الحزينة عن أضرار التوقيف في القانون العراقي والكوردستاني}

قد ينتهي التحقيق الذي أجري مع المتهم الذي قضى فنزة من الزمن في التوقيف إلى إصدار القرار برفض الشكوى وغلق الدعوى نهائياً())، أو بالافراج عنه لعدم توفر أدلة الإحالة(\&)، أو يتم إحالته إلى الخكمة المختصة ولكن هذه الأخيرة لاتقتنع بقيام المتهم بإقز اف الفعل أو أن الفعل لايعاقب عليه قانوناً أو تقتنع بأن الأدلة غير كافية لإدانته، فنصدر قراراها بالبراءة والإفراج حسب الأحوال (•) وليس من شك في أنه يكون قد ترتبت على توقيفه أضراراً بالغة له، فليس أعز على الإنسان من حريته التي يسلبها منه إجراء التوقيف، فوق الإساءة البالغة لسمعة الموقوف، فضلاً عن الأضرار المادية التي ترتبت على تعطيل أعماله فنزة توقيفه. لذا فإن المنطق القانوني وقواعد العدالة يقضيان ضرورة تعويضه عن تلك الأضرار(،).

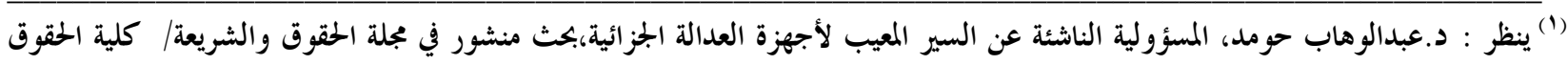

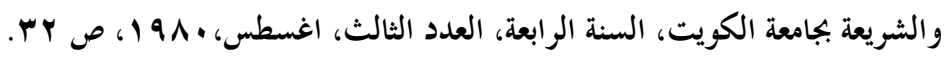

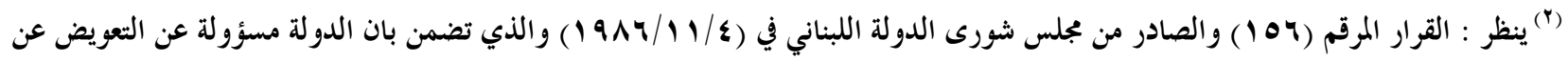

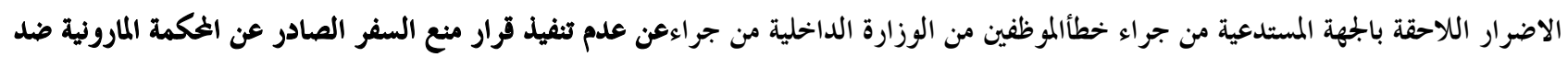
المدين. منشور في الموقع الالكمروني . /2014 // צlast visit http://www.statecouncil.gov.lb/view2.asp?id=164 وللمزيد حول الخطأو إنعقاد مسؤولية الدولة منه ينظر : حبيب فارس نمور، مصدر سابق، ص 9 ب وما بعدها.

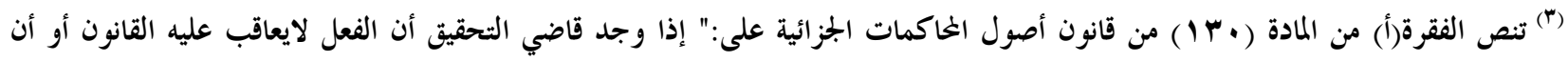

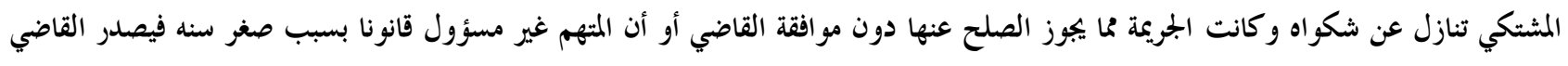

قرار برفض الشكوى وغلق الدعوى نهائيا.".

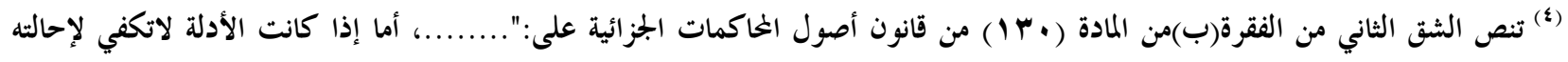

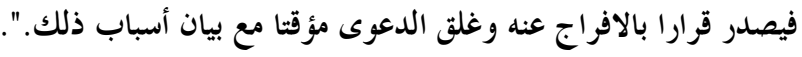

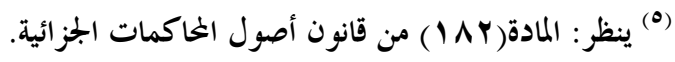

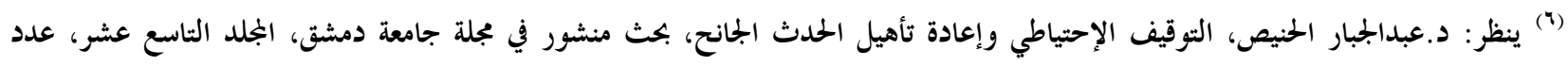


إن قرار التوقيف يعد من القرارات التي يصدره القاضي خلال مزاولته لعمله القضائي كنوع من السلطة التقديرية(1)

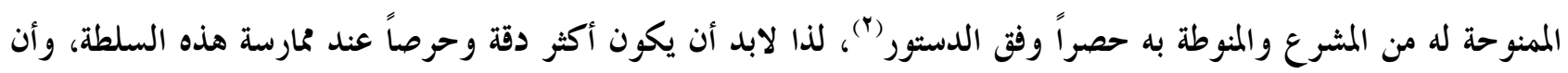
يتحقق من توافر ضوابط وشروط هذا الإجراء فضلاً عن التأكد من أن توقيف المتهم سيحقق الأهداف والمبررات التي وضع ألمع التوقيف من أجلها، وأن لايجعل منه وسيلة لإرغام الموقوف بقبول طلبات المثتكي أو المدعي بالحق المدني والتصالح معه رغم حقوقية الدعوى وإفتقارها للعنصر الجزائي. وعند رجوعنا إلى الأحكام القانونية الخاصة بالتوقيف، يتبين لنا بان المشرع قد أدرك خطورة هذا الإجراء جيدا، حينما خطى خطوات في سبيل درء المساويء الناجة عنه تارة وتخفيفها تارة أخرى، وذلك بإحاطته بسياج من الضمانات، منها أنه قد

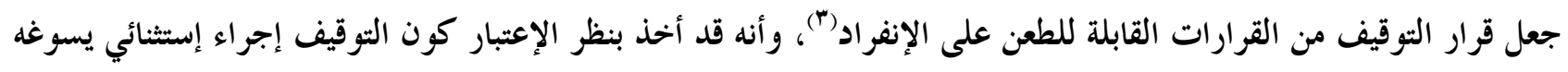
ضرورات عملية مهمة، لذا فهو إجراء مؤقت بحكم طبيعته ولابد أن ينتهي بإنتهاء الضرورات التي دعت إليه، ومن هذا المنطلق قد قيد المشرع سلطة القاضي في أن يأمر بتوقيفه لمدة لاتزيدعلى(ه (1)يوماً في كل مرة، وهذا يعني أن للقاضي سلطة تقديرية في تحديد مدة التوقيف من (ع Y) ساعة إلى (ه 1) يوما، وذلك لأن النزول بهذه المدة يكون من مصلحة المتهم وبالتالي فهر ضمانة

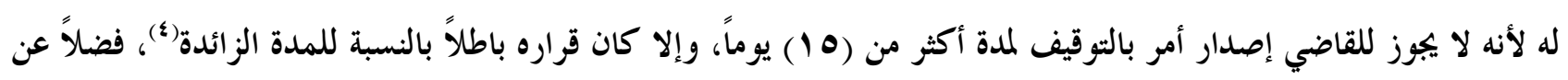
ذلك أوجب القانون تمديد مدة التوقيف عند إنتهاء المدة الأولى، بحيث لايجوز أن يزيد مجموع مدد التوقيف على ربع الحد الاقصى للعقوبة ولا يزيد بأية حال على ستة أشهر وإذا اقتضى الحال تمديد التوقيف اكثر من ستة اشهر، فعلى القاضي عرض الأمر على محكمة الجنايات لتأذن له بتمديد التوقيف مدة مناسبة على أن لا تتجاوز ربع الحد الاقصى للعقوبة أو تقرر إطلاق

سر احه بكفالة).(•)

بالإضافة لهذه الضمانات المثوفرة للمتهم الموقوف، فإن المشرع وبموجب قانون الإشراف القضائي قد خول عضو الإشراف القضائي مهمة الرقابة والإشراف على الأجهزة القضائية، وملاحظة اعمالها وحسن سير تطبيق القانون فيها. حيث أن المشرف القضائي إذا وجد تقصير من قاضي كما لو كان هذا القاضي قد اتخذ قراراً تعسفياً في توقيف شخص ما، وكان في هذا القرار قد خالف القواعد المتعلقة بالتوقيف وانخرف في سلطته، فإنه قد يجري التحقيق فوراً بهذه المخالفة بعد أخذ أذن مجلس القضاء

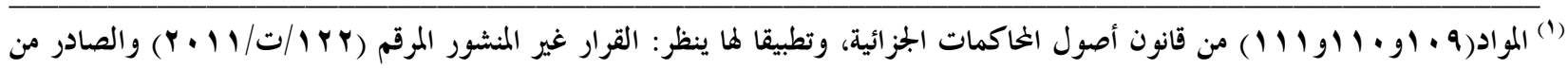

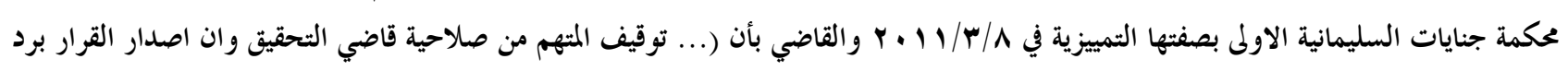
طلب المتهم الموقوف لاطلاق سر احه بكفالة يخضع لسلطته التقديرية حسب متطلبات التحقيق ...) .

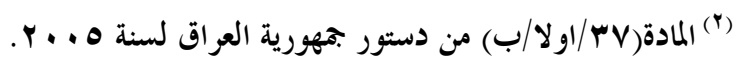

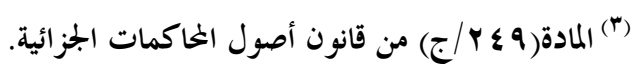

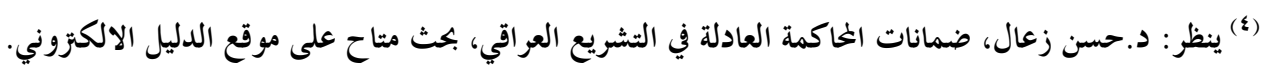
last visit 3/2/2014 http://www.fcdrs.com/articles/113.html 
الأعلى، وفي هذه الحالة تكون صلاحياته هي صلاحيات قاضي تحقيق في هذه القضية(1)، هذا من جانب ومن جانب آخر فإن جهاز الإدعاء العام هو الآخر يقوم بدور مراقبة المشروعية عن طريق تقديم المطالعات أو إعمال طرق الطعن في القرارات المبنية على خرق للقانون أو تعسف في ممارسة سلطته(؟). وعلى هذا الاساس لايجوز لقاضي التحقيق تجاوز الحدود المرسومة له قانوناً أو التعسف في إستعمال السلطة الممنوحة له في التوقيف، وأن أي خلل بتطبيق القواعد القانونية أو الإنحراف في ممارسة تلك السلطة، يعتبر إخلالاً بشرعية القرار الذي يصدره، ويعرض نفسه أولاً للمساءلة القانونية(")، وثانياً يكون مصير عمله البطلان نتيجة إعمال طرق الطعن منه، مما يؤدي إلى بطلان كافة الإجراءات المبنية عليه لأن ما بني على الباطل فهو باطل(ع). أن توفير هذه الضمانات وإتخاذ كل هذه الإحتياطات في التوقيف، يهدف إلى درء الضرر من المتهم ويعد محاولة من المشرع في سبيل عدم سلب الحرية إلا لضرورات تستدعي ذلك، ولكن السؤال الذي يطرح نفسه في هذا المقام هو هل أن التحقق من توفير هذه الضمانات وإتخاذ تلك الإحتياطات يحول دون إلحاق الضرر بالمتهم؟ أي هل أن هذه الضمانات مانعة من حدوث الضرر؟ وهل بإمكان طريق الطعن إزالة الضرر الناجم عن التوقيف؟ هذا ما نحاول الإجابة عنه أدناه.

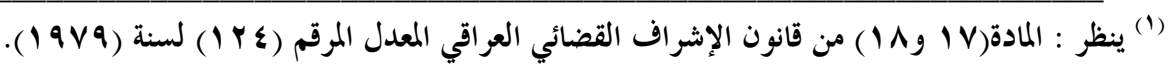

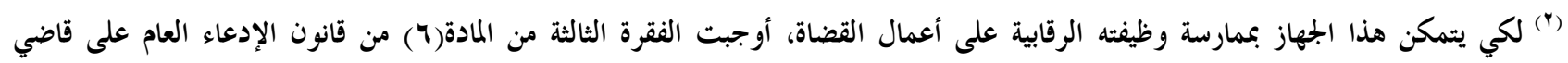

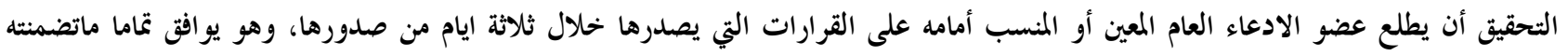

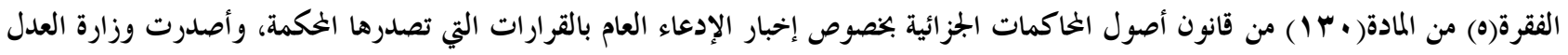

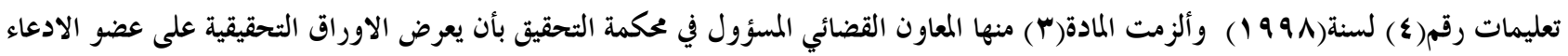

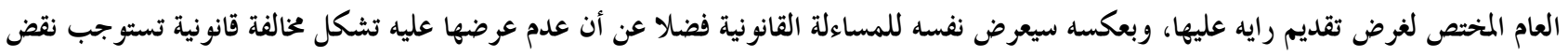

المآ) يتنوع شكل هذه المساءلة حسب السلوك الذي إقزفه القاضي، فإذا كان السلوك الذي اقزفه القاضي يشكل جريمة، فان شكل المسؤولية هو

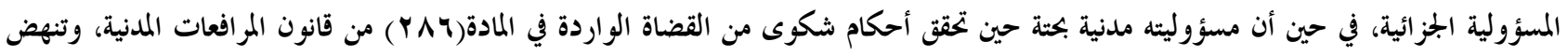

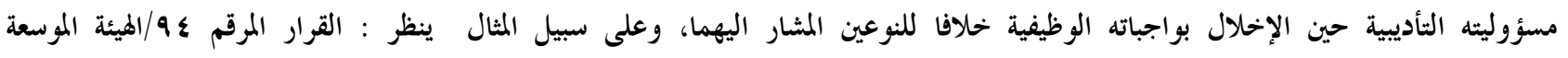

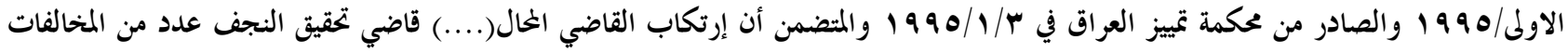

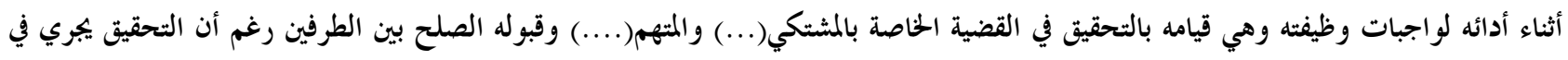

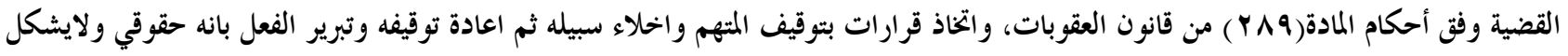

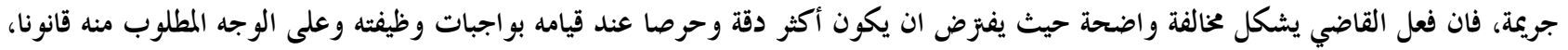

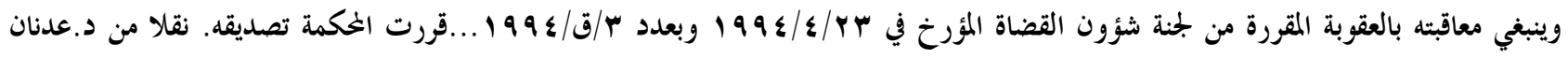

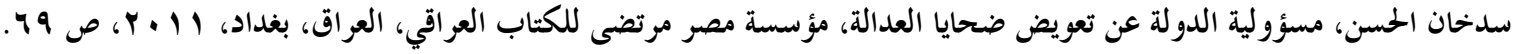

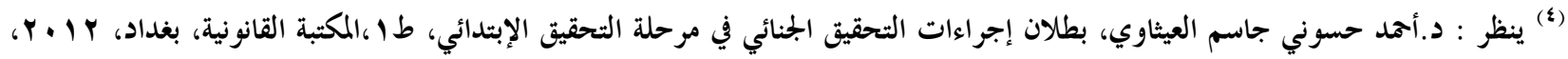


أن تعويض المتهم الموقوف يكون على نوعين، أولمما يتعلق بالمتهم الموقوف، وتتبين للمحكمة بأنها على حق في توقيفه لإثبات التهمة الموجهة إليه، ويكون تعويضه في شكل خصم أو تنزيل المدة التي أمضاها موقوفاً من مدة العقوبة الخكوم بها عليه،

$$
\text { وأن بحث هذه الصورة من التعويض تكون خارجة عن موضوع دراستنا('). }
$$

أما النوع الثاني من التعويض هو المتعلق بالمتهم الذي يمضي فنزة من الزمن في التوقيف، وتتوصل الخكمة إلى أنه أما لم يرتكب الفعل المسند اليه ، أو أن الفعل المسند إليه لايعاقب عليه قانوناً، أو أن القضية مفتقرة للدليل مما يستوجب الإفراج عنه، أو أن الدليل المتحصل في الدعوى غير كاف لإدانته. وأن الضرر الناجم عن هذا الإجراء هو الذي من الواجب التعويض عنه ولايمكن الإستغناء عنه، لأن الشخص الذي يسلب منه حق الحريةهو الذي يعرف قيمثها وإحزامها. ولكن حين صدور مثل هذه القرارات التي تتضمن الإفراج أو البراءة عن المتهم، يتبين لنا أولاً مناقضة التوقيف لأسىى الحقوق الدستورية الواجبة إحتزامها

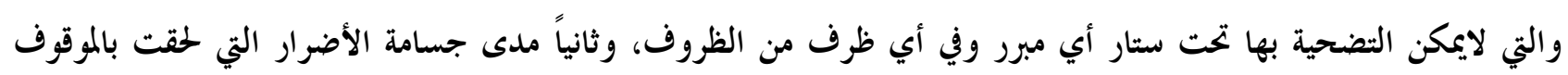
والتي كانت غائبة في بال المشرع والتي من المفروض أن ينظر إليها بنظرة بعيدة، بحيث يوضح من بعدها صورة الإجراء ومآلـهـ و آثاره لأن التعويض بالمال و إن كان لايعيد للإنسان شرفه المثلوم، إلا أنه قد يشفي بعض جراحه. أن المشرع العراقي وعلى الرغم من توفير ضمانات عدة للمتهم الذي يبقى في المواقف طوال مدة توقيفه، إلا أنه هو الآخر الذي لم يمنح الحقى للمتضرر مطالبة التعويض لإصلاح الأضرار المادية والمعنوية التي لحقته جراء ذلك الإجراء، مما يدفعنا المى القول بانه ووفقاً للتشريع العراقي الحالي لايجوز للمتضرر من التوقيف مطالبة التعويض عن الأضرار الناجة عن توقيفه ولو كان هناك تعسف في إستعمال سلطة التوقيف أو كان القرار مخالفاً للقانون. إلا إن إطلاق هذا الحكم وفي هذه المناسبة لايحول دون إمكان المتضرر من مخاصمة القاضي ومطالبته بالتعويض حين تحقق حالاتـــها، لأن هذه الدعوى تهدف إلى كشف إنحراف القاضي عن جادة الحق، وما يتزتب على ذلك من بطلان الإجراء الذي قام به القاضي المخاصم، وبالتالي مسؤوليته عما لحقه من ضرر مادي ومعنوي(ז)، فضلاً عن إمكانية الرجوع بالتعويض على من تسبب في توقيفه كالمشتكي الذي يتعسف في شكواه ويثبت كيديته والمبلغ الذي يبلغ بسوء النية أو الشاهد الذي كان عالماً بكذب ما أدلى به في شهادته تطبيقاً للأحكام العامة في المسؤولية التقصيرية، لأن ماجرى عليه العمل في القضاء وما اتفق عليه الفقه هو أن الإستخدام التعسفي للحقوق بصورة عامة وحق

(1) للمزيد حول طريقة الخحم وكيفية معالجتها التشريعية، ينظر : د.سردار على عزيز، ضمانات المتهم في مواجهة القبض والتوقيف، دراسة مقارنة،

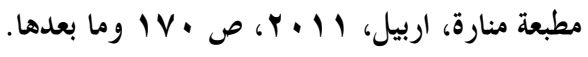

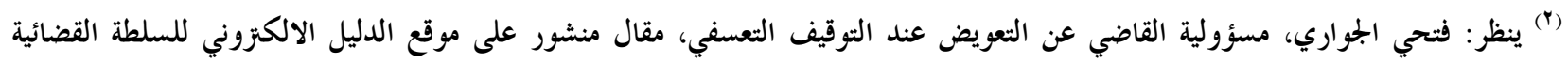


التقاضي والحقوق الإجرائية بصورة خاصة من الحقوق التي تنهض المسؤولية المدنية من ممارسته(1)، وفوق ذلك فإن المشرع قد جعل وفي موضع آخر أن ثبوت غش الخصوم(() و كذب مضمون شهادات الشهود(") من أسباب تعديل الحكم الذي بني عليهما إصدار حكم جديد في الدعوى(\&)، لذا فمن باب أولى أن تجعلها سنداً للمطالبة بالتعويض حين ثبوتهما. إن المشرع العراقي لم يكن موفقاً في معالجته لموضوع التوقيف حينما أكتفى بإحاطة هذا الإجراء ببعض الضمانات والإحتياطات دون التعرض لما يتزتب على ذلك الإجراء من الأثر خاصة حينما لم يصيب الإجراء هدفه سواء بالإهمال أو القصد بسبب موت الضمير وفقدان الإحساس بالواجب المهني. لذا فإن المشرع العراقي مطالب بالتدخل الإيجابي في الوضع القانوني الراهن وتعديل الأحكام التي بحاجة إلى التعديل سواء على شكل تشريع مستقل ينظم كافة الأحكام المتعلقة بالمسؤولية عن الأعمال القضائية ومنها التوقيف، أو بإضافة مواد جديدة إليها بحيث يمنح المتضرر مطالبة الدولة بالتعويض عن الأضرار المادية والمعنوية).(•)

وتلبية لمثل هذه الدعوات وإستجابة للتوجهات الرامية لإنصاف المظلومين ومن وقع بحقهم إجحاف، إتجه البرلمان العراقي إلى تشريع قانون بإسم( قانون تعويض ضحايا العدالة)، ويهدف المشروع إلى تعويض بعض الأشخاص عن الأضرار التي لحقت به، وهم " أولاً: احتجز أو أوقف تعسفاً. ثانياً: تجاوزت مدة موقوفيته الحد المقرر قانوناً. ثالثاً: حكم عليه من إحدى الخاكم المختصة نتيجة خطأ فاحش وصدر قرار لاحق برفض الشكوى أو بالافراج عنه وفق الدعوى أو الحكم ببراءته واكتساب القرار لدرجة البتات. وأتى المثروع بحكم جديد وهو إلزام خزينة الخافظة التي يقيم فيها الشخص المتضرر الذي صدر قرار الحكم البات لصالحه بصرف مبلغ التعويض، فضلاً عن إحتوائها لنصوص أخرى لم يكن لها مثيل في العراق، ولكن نجد بأن هذه النصوص لحد هذه اللحظة باقية كمشروع في رفوف البرلمان ولم تر النور("). أما بالنسبة لإقليم كوردستان وعلى الرغم من نفاذ قانون أصول الخاكمات الجزائية والذي أحكامه كما بينا خالية من التعرض لبحث المسؤولية المدنية عن التوقيف، وإعطاء المتضرر حق مطالبة التعويض، إلا أن برلمان كوردستان سرعان إستشعر

(1) للمزيد عن هذا الموضوع ينظر: د. أحمد إبراهيم عبدالتواب ، الإساءة في إجراءات التقاضي والتنفيذ ، دار الجامعة الجديدة ، الأسكندرية،

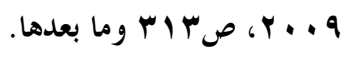

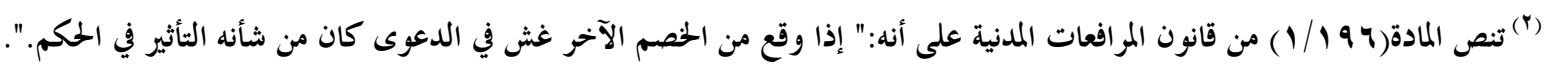

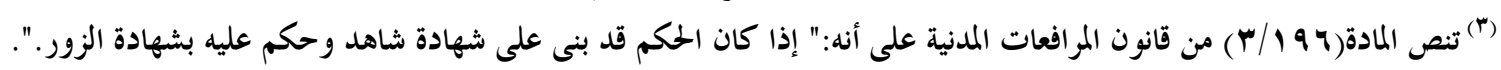

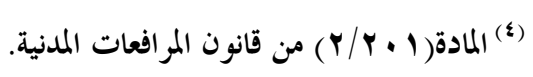

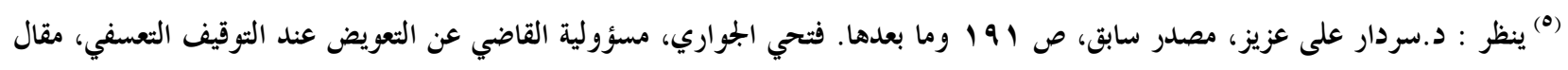
منشور على موقع الدليل الالكتزوني للسلطة القضائية الإتحادية. last visit 4/2/2014/Vr.http://Www.iraqja.iq/view.

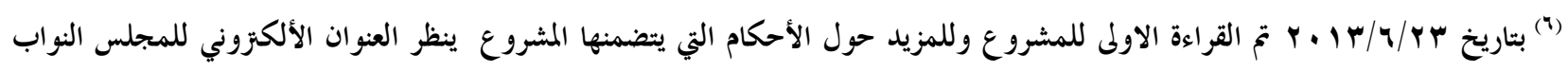
last visit 4/2/2014 ^r^http://ar.parliament.iq/LiveWebsites/Arabic/Container.aspx?LawID= 
بخطورة هذا الإجراء وآثاره الذي يمس حريات الأشخاص ويقيدها، خاصة وأنه يتخذ ضد شخص مازال يعد بريئاً في نظر القانون. من هنا وإنطلاقاً من مقتضيات العدالة ولشيوع مفاهيم الحرية الشخصية للافراد، وعدم جواز المساس بها إلا طبقاً لما هو منصوص عليه في القانون ، وتجسيداً لما أقرته أكثرية الدساتير في الدول المتحضرة، ومنها الدستور العراقي لسنة ه ه. ب من ضرورة ضمان الحرية الشخصية للافر اد، فلقد خطى المشرع الكردستاني في أقليم كردستان العراق خطوة جريئة، وعلى غاية من الأهمية لتجسيد ضمان الحرية الثخصية وعدم جواز المساس بها إلا طبقاً للأصول القانونية، وذلك في نصوص قانونية واضحة وصريحة تضمن عدم المساس بالحرية الشخصية للأشخاص الذين يتم حجزهم أو توقيفهم أو الحكم عليهم بعقوبة سالبة للحرية ومن ثم صدور قرار بالإفراج عنهم أو ببراءتهم من التهمة المنسوبة إليهم، وذلك من خلال تشريع قانون تعويض الموقوفين

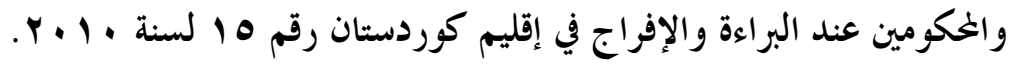
حيث وفر هذا القانون نوعين من الضمانات للمتهم الموقوف، والنوع الأول عبارة عن الضمانات التي تتعلق بالمرحلة التي هو في الموقوفية والمتمثلة بحصر سلطة التوقيف لجهة قضائية مختصة وعدم جواز التوقيف إلا في أماكن مخصصة له، فضلاً عن تمتع الموقوف بالرعاية الصحية والإجتماعية وإحتزام معتقداته الدينية ومبادئه الأخلاقية(1)، والنوع الثاني من الضمانات عبارة عما يتمتع به الموقوف الذي يثبت برائته أو يفرج عنه أو يثبت بان قرار توقيفه لم يكن في محله بل ناجم عن تعسف القاضي في سلطته، وفي هذه الأحوال فإن هذا القانون قد منحه حق مطالبة التعويض عن الأضرار المادية والمعنوية التي لحقت به، فضلاً عن نشر قرارات الحكم بالبراءة والإفراج لمن ثبتت براءته أو إفراج عنه في صحيفتين يوميتين في الاقليم "( .

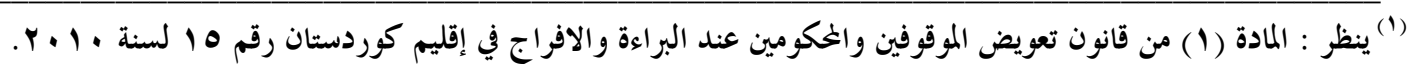

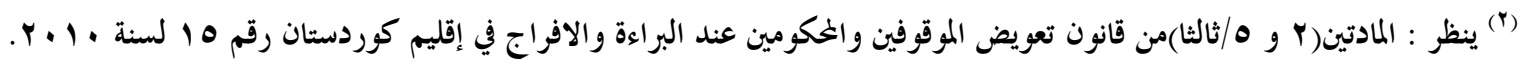




\section{الإستنتاجات}

1 ـ هناك إختلاف واضح في موقف مشرعي الدول حين معالجة مسؤولية الدولة عن الأضرار الناجة عن الأعمال غير المشروعة المنسوبة المى الجهاز القضائي، ويعود سبب هذا الإختلاف إلى تأثير قاعدة عدم مسؤولية الدولة تجاه الأعمال القضائية ورغبة المشرع من عدم التوسع في دائرة مبدأ المسؤولية عنها، وهذا واضح من خلال دراسة طريقة معالجة تلك الدول لهذا

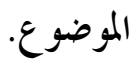

r. لم تلطرق الثشريعات إلى منح حق رجوع المتضرر على الشاهد أو المبلغ أو المتسبب ومطالبتهم بالتعويض، وهذا لايحول

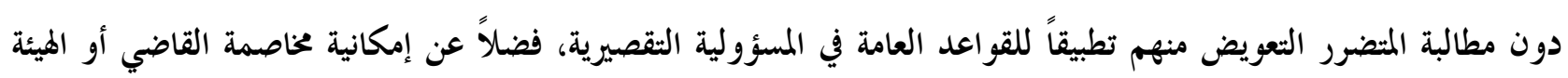
التي أصدرت الحكم إذا تو افرت حالات الشكوى من القضاة. r. إتجهت التشريعات المقارنة إلى توفير محاية قانونية جزئية وناقصة لمتضرري الأعمال القضائية بدليل أن القاضي يمارس

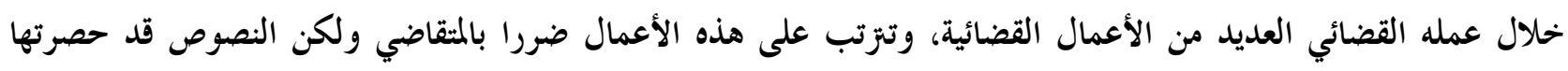
ببعض الحالات التي يستحق فيها المتضرر التعويض دون بحث الأخرى.

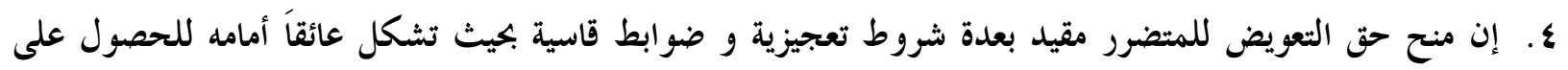
التعويض، مثل إتباع شكلية معينة في المطالبة أو حصر تقديم طلب التعويض بمحكمة معينة.

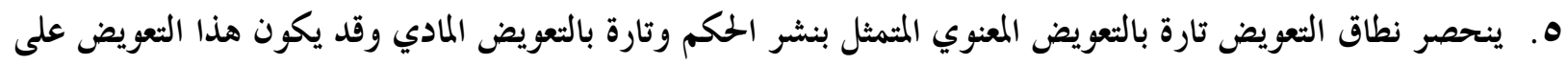
شكل خصم مدة التوقيف من العقوبة.

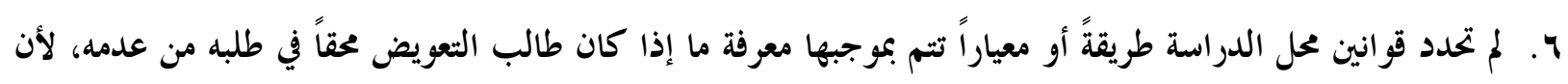
العبارات الواردة في النصوص جاءت بصيغة تتحمل أكثر من معنى، مما تسبب في رد الكثير من الطلبات المقدمة إلى لجان التعويض.

V. أخذ المشرع الكوردستاني بفكرة تحمل التبعة كأساس للمسئولية المدينة الناجمة عن التوقيف، وبذلك قد خطى خطوة أكثر تقدماً وتطوراً. 1. أن التشريعات التي أقرت حق التعويض للمتضرر قد حددت مدة للتقادم ولكنها قصيرة جداً وإن الرجوع إلى القواعد العامة في القانون المدني قد تغنينا عن ذلك. 
بناء على ما توصلنا إليها من إستنتاجات تبين لنا عرض التوصيات والمقزحات الآتية : 1 ا نقتزح على المشرع العراقي والكوردستاني أن يخرجا من إيراد إستثناءات على مبدأ عدم المسؤولية المدنية عن الإعمال

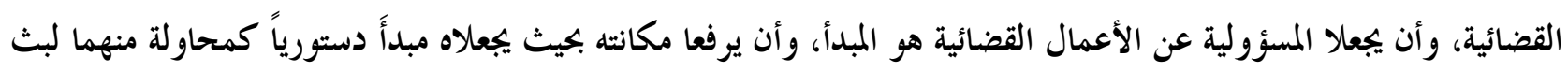

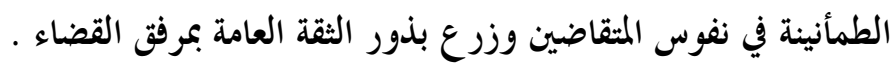
r. ضرورة إصدار تشريع مستقل تجمع شتات النصوص المبعثة في القوانين المختلفة بخصوص تعويض المتقاضي، بحيث يراعي في سنه جملة قواعد منها سمو الحق، وتعويض المثضرر، وقيمية النصوص بحيث ينظر إليها بأنها خادمة للحق. r. نقزح على المشرع الكوردستاني أن يعدل نص المادة(§ ( )من قانون مكافحة الإرهاب بحيث يجعله كالآتي:" للمتهم بالجريمة الإرهابية الذي تثبت برائته عن التهمة اليه من المطالبة بالتعويض عما لحقه من ضرر مادي ومعنوي.". لأن ما اشتزطته

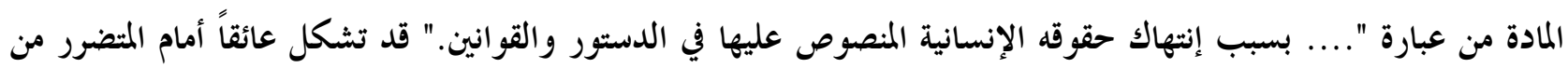
الوصول إلى حقه. ع. نقتزح على المشرع الكوردستاني أن يعدل الفقرة الأولى من المادة(ب)من قانون تعويض الموقوفين والخكومين عند البراءة والإفراج في إقليم كوردستان رقم 10 لسنة ـ1 + ب بحيث يعطي الإختصاص لنظر دعاوى التعويض بمحكمة بداءة محل إقامة المتضرر وتنظر في الدعوى بدرجتها الأولى، وأن يجعل الحكم قابلاً للإستئناف والتمييز . ه. نقزح على المشرع الكوردستاني أن يعدل نص الفقرة (ثانيا)من المادة(؟)من قانون تعويض الموقوفين والخكومين عند

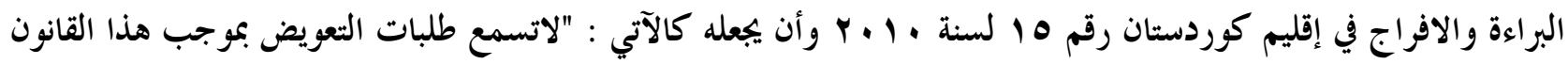
بعد مرور ثلاث سنوات على إكتساب قرار الإفراج أو الحكم بالبراءة درجة البتات.". 
1 ـ. ـ.إدريس عبدالجواد عبدالله بريك، الحبس الإحتياطي ومماية الحرية الفردية في ضوء آخر تعديلات قوانين الاجراءات

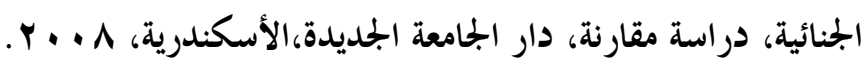

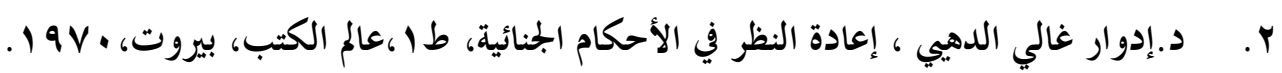

ץ. د. أحمد إبراهيم عبدالتواب ، الإساءة في إجراءات التقاضي والتنفيذ ، دار الجامعة الجديدة ، الأسكندرية، 9 ـ . . . ع. د.أحد حسوني جاسم العيثاوي، بطلان إجراءات التحقيق الجنائي في مرحلة التحقيق الإبتدائي، طا،المكتبة القانونية،

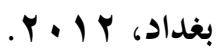
ه. د.أنور أحمد رسلان،القضاء الاداري - قضاء التعويض(مسؤولية الدولة غير التعاقدية)، دار النهضة العربية، قاهرة،

7. د.براء منذر عبداللطيف، شرح قانون أصول الخاكمات الجزائية،

V. . د. جابر جاد نصار، مسؤولية الدولة عن أعمالها غير التعاقدية(قضاء التعويض)، دار النهضة العربية، القاهرة، 999 1. ^. حبيب فارس نمور، الأخطاء والمخاطر في القانون الإداري، طا، مطبعة المتني ، ب999 19. 9 . د.خلف الله أبو الفضل عبدالرؤوف، القبض على المتهم في ضوء الفقه والقضاء والتشريع المصري والفرنسي

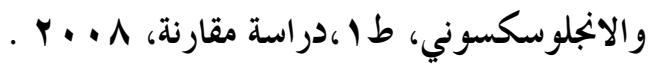
• . . رحيم حسن العكيلي، الإعتزاضات (الاعتزاض على الحكم الغيابي واعتزاض الغير في قانون المرافعات المدنية)، مكتبة صباح، بغداد، دون سنة الطبع · ا1. د.رزطار محمد قادر، التوقيف ومعاملة الموقوفين في ظل قواعد وأحكام القانون الدولى لحقوق الإنسان، مركز أبحاث

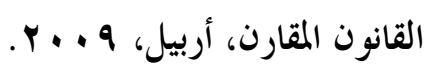
ץ ا ـ د.رؤوف عبيد، مباديء الإجراءات الجنائية في القانون المصري، مكتبة الوفاء القانونية، طم ا، القاهرة .

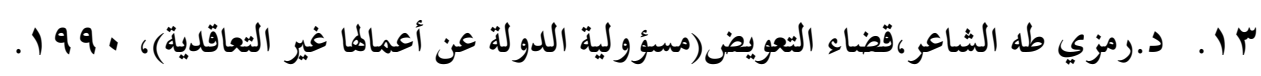
ع ا. ـ سامي سليمان فقى، نظام الوضع تحت المراقبة القضائية، دراسة تحليلية مقارنة، مركز أبحاث القانون المقارن، أربيل، $6 \% \cdot 9$

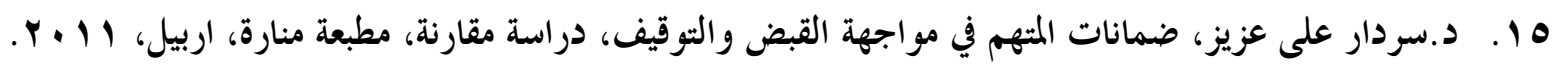

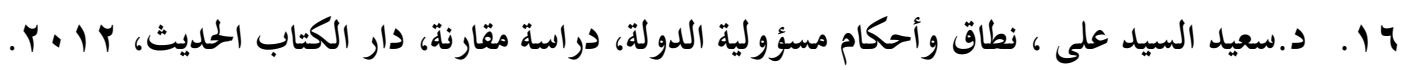
V . . سعيد حسب الله عبدالله، شرح قانون أصول الخامات الجزائية، دار إبن الأثير للطباعة والنشر، موصل. 
^ا ـ. د.طارق صديق رشيد طةردي، حاية الحرية الشخصية في القانون الجنائي، دراسة تحليلية مقارنة، طا، مطبعة آراس، أربيل $r \cdot . q$ ،

9 1 . . د. طه زاكي صافي، الإتجاهات الحديثة للمحاكمات الجزائية(بين القديم والجحيد)، طا،مجد المؤسسة الجحامعية للدراسات والنشر والتوزيع، ب. r. r. • •. . د.عدنان سدخان الحسن، مسؤولية الدولة عن تعويض ضحايا العدالة، مؤسسة مصر مرتضى للكتاب العراقي، العراق، بغداد، I| ب r ا ا.. د.عبدالحميد الشواربي ، المسؤولية القضائية في ضوء الفقه والقضاء، منشاة المعارف بالأسكندرية. r Y . . . د.عبدالوهاب حومد، المسؤولية الناشئة عن السير المعيب لأجهزة العدالة الجزائية. r.Y. د.فاضل زيدان محمد، سلطة القاضي الجنائي في تقدير الأدلة، دراسة مقارنة، طا،دار الثقافة للنشر والتوزيع،عمان، .$r \ldots r$

ع Y. . د.فتحي فكري، مسؤولية الدولة عن أعمالها غير التعاقدية، دار النهضة العربية،القاهرة، هـ 99 ـ.

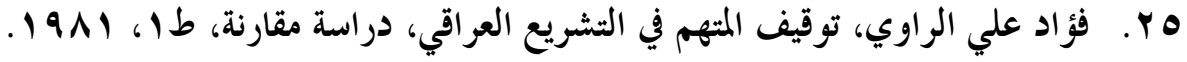

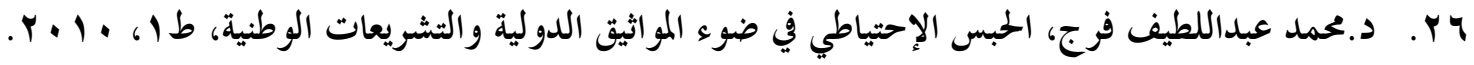
V V. . . دمحمد عبدالواحيد الجميلي، قضاء التعويض(مسئولية الدولة عن أعمالها غير التعاقدية)، دار النهضة العربية، القاهرة، $.1999-1990$

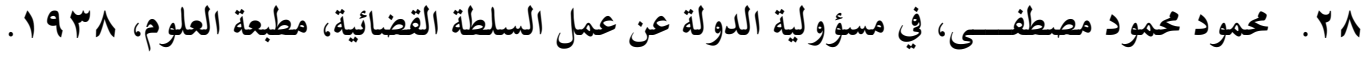

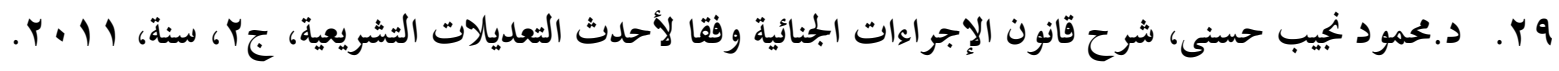

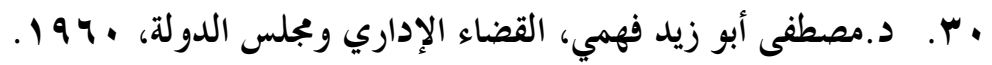
اس. . د. يس عمر يوسف،استقلال السلطة القضائية في النظامين الوضعي والإسلامي، دار ومكتبة الهلال. ץ. Y. . هدى بشير الجامعي، مسؤولية الدولة عن أعمال السلطة القضائية، دراسة تحليلية، دار المطبوعات الجحامعية.

ثانياً : الرسائل والأطاريح الجامعية ا. أحمد سعدي سعيد الأحد، المتهم ضماناته وحقوقه في الإستجواب والتوقيف(الحبس الاحتياطي) في قانون الإجراءات الجزائية الفلسطيني، دراسة مقارنة، رسالة ماجستير قدمت لكلية الدراسات العليا بجامعة النجاح الوطنية بنابلس، فلسطين، م م. . . . Y. بلولهي مراد، الحدود القانونية لسلطة القاضي الجنائي في تقدير الأدلة، مذكرة مقدمة لنيل شهادة الماجستير في العلوم

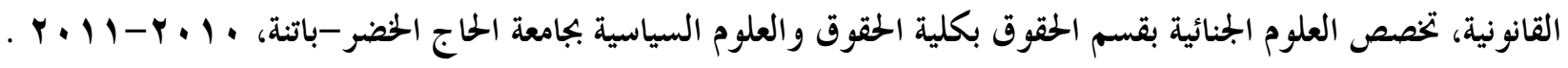


r. سيروان رؤوف علي، التعسف القضائي والمسؤولية المدنية الناجمة عنه، دراسة تحليلية، رسالة ماجستير قدمت لكلية القانون

والسياسة بجامعة السليمانية، ع ا م. ب.

ثالثاً:البحوث والمقالات

ا. د.فواز صالح، التوقيف المؤقت في القانون الفرنسي في ظل التعديلات الجحديدة الصادرة بقانون رقم (7 اهـ) بتأريخ ه/ / / . . . . . بحث منشور في مجلة الحقوق الكويتية، العدد الرابع، السنة السادسة والعشرون،شوال بrع (ه-ديسمبر Pr. r r

r. عباس زواوي، الحبس المؤقت وضماناته في التشريع الجزائري، بحث منشور في مجلة المنتدى القانوني، مجلة أصدرتها كلية الحقوق والعلوم السياسية، قسم الكفاءة المهنية للمحاماة بجامعة محمد خيضر بسكرة، جزائر، العدد الخامس، مارس ج + . Y. ب. . د.حسن عودة زعال، ضمانات الخاكمة العادلة في التشريع العراقي، بحث متاح على موقع الدليل الالكتزوني التالي:

http://www.fcdrs.com/articles/113.

ع. فتحي الجواري، مسؤولية القاضي عن التعويض عند التوقيف التعسفي، مقال منشور على موقع الدليل الالكتزوني للسلطة القضائية الإتحادية .

/ Vr.http://www.iraqja.iq/view.

ه. . د.حسن عودة زعال، ضمانات الخاكمة العادلة في التشريع العراقي، بحث متاح على موقع الدليل الالكتزوني التالي: http://www.fcdrs.com/articles/113.html

I. د.عبدالجبار الحنيص، التوقيف الإحتياطي وإعادة تأهيل الحدث الجانح، بحث منشور في مجلة جامعة دمثق، الجلد التاسع

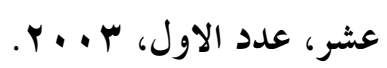
V. وليد اوتر موند، حبس المؤقت في ظل التعديل الاخير لقانون الإجراءات الجزائية- قانون رقم (N) في ( 1 + . المعدل لقانون الإجراءات الجزائية الجزائري، بحث منشور على الموقع الإلكتروني التالي: ๑ จ $\mathrm{rhttp://montada.echoroukonline.com/showthread.php?t=}$ 
رابعاً : الدساتير و القوانين

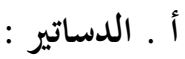

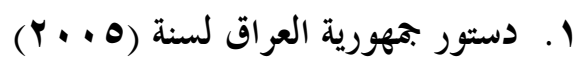

r. الدستور المصري لسنة (19V1)

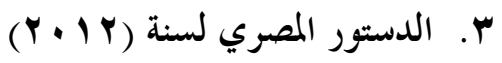

ع. الدستور الجزائري لسنة (1997)

ب. ب القوانين والتعليمات العراقية :

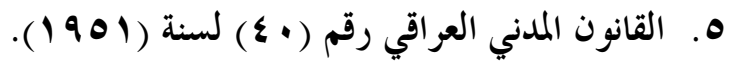

ج. قانون المرافعات المدنية العراقي رقم (T) لسنة (1979)

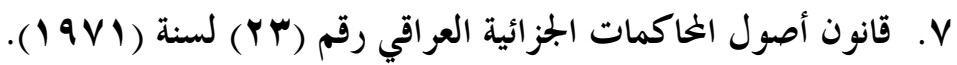

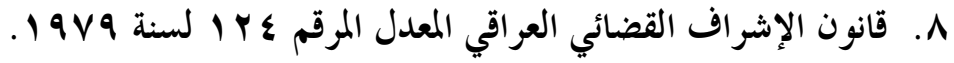

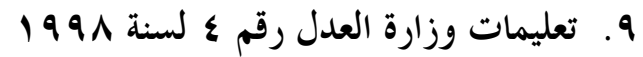

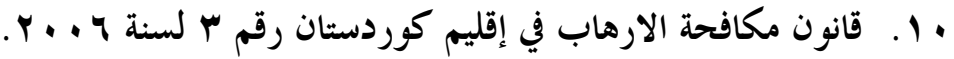

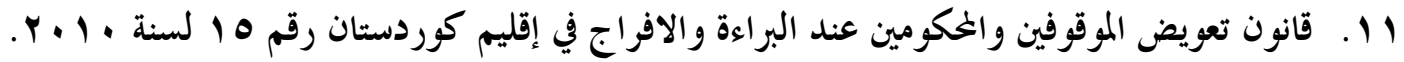

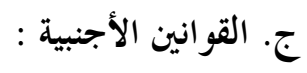

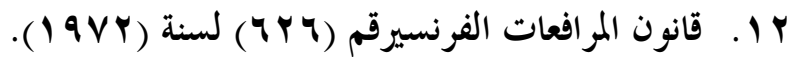

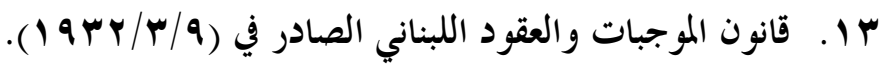

ـ ا. قانون الإجراءات الجنائية المصري رقم (10.1 لسنة (1900) المعدل .

10 ـ قانون الإجراءات الجنائية الجزائريةرقم (100) لسنة (47 (197) المعدل .

17 . . قانون الإجراءات الجنائية الليبي لسنة (به 9 ( ) المعدل.

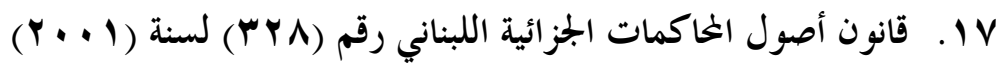

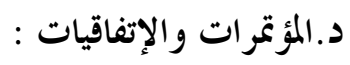

11. المؤتمر الدولى السادس والعشرين لقانون العقوبات المنعقد في روما اكتوبر (به9 1).

19. الإتفاقية الاوروبية لحقوق الانسان لسنة (1900). 